\title{
An annotated checklist slime molds \\ (Myxomycetes = Myxogastrea) of western Kazakhstan
}

\section{Inna Zemlyanskaya ${ }^{1}$, Yuri Novozhilov ${ }^{2}$, Martin Schnittler ${ }^{3}$}

1 Volgograd State Medical University, Pavshikh Bortsov Square 1, Volgograd 400131, Russia

2 Laboratory of Systematics and Geography of Fungi, Komarov Botanical Institute of the Russian Academy of Sciences, Prof. Popov Str. 2, St. Petersburg 197376, Russia

3 General Botany and Plant Systematics, Institute of Botany and Landscape Ecology, University Greifswald, Soldmannstr. 15, Greifswald 17487, Germany

* Corresponding author: ignis@list.ru

Keywords: Amoebozoa, arid regions, biodiversity, steppe, desert, slime molds, species inventory, Myxogastria, Kazakhstan

Article info:

Received: 4 August 2020

Accepted: 11 September 2020

Published online: 13 October 2020

Corresponding Editor: Nikki Heherson A. Dagamac

Assistant Editor: Oleg Schchepin

\section{Abstract}

Winter-cold arid regions of western Kazakhstan were surveyed for myxomycetes for a period of 20 years. A total of 3228 records belonging to 111 species from 31 genera and 10 families are provided in an annotated checklist. The checklist contains data on the localities, habitats, substrates, methods of collection and voucher numbers of specimens deposited in the mycological herbarium (LE) of the V.L. Komarov Botanical Institute of the Russian Academy of Sciences. Additionally the bibliographic references of the myxomycete species findings in the study area are given. Due to the very arid climate of the region, 2911 specimens (ca. 90\%) were obtained from 1653 moist chamber cultures prepared with samples taken from bark of living plants, litter and the weathered dung of herbivorous animals. Only 317 specimens of myxomycetes were collected directly in the field, mostly in woody artificial plantations. The lowest species diversity was observed in habitats with halophytic vegetation, where on average only 1-2 species were recorded per moist chamber culture. Only Perichaena depressa and $P$. 
liceoides were common under such conditions. The highest diversity of myxomycetes was observed in the intrazonal woody communities of the steppe zone, which are usually associated with river valleys and artificial woody plantations. In these habitats lignicolous species occurred: Amaurochaete atra, Arcyria obvelata, Cribraria cancellata, Lamproderma scintillans, Lycogala epidendrum, Metatrichia vesparia, Oligonema flavidum, Stemonitis axifera, S. fusca, S. herbatica, S.pallida, Symphytocarpus confluens, and Trichia contorta. However, the apparently most common species of myxomycetes in the studied area are associated with litter or bark: Badhamia foliicola, B. spinispora, Didymium anellus, D. difforme, D. trachysporum, Echinostelium colliculosum, Fuligo cinerea, Licea denudescens, L. nannengae, L. parasitica, Macbrideola oblonga, Pericaena depressa, $P$. corticalis, P. liceoides, $P$. vermicularis, Physarum cinereum, and Ph. pseudonotabile. Among substrate types, species diversity and richness decrease from wood over ground litter to bark, and dung of herbivorous animals. Shannon diversity and species richness reached maximum values in the intrazonal and artificial woody communities, whereas treeless sagebrush desert and dry steppe communities and, halophytic vegetation had the most depauperate yet most specific myxomycete assemblages. Assemblages associated with these vegetation types displayed a high level of similarity to those of myxomycete assemblages from other arid regions of Kazakhstan and Central Asia. In contrast, assemblages of the artificial woody plantations in the study region displayed a high level of similarity to those of boreal forest regions of Siberia for which data exist, but differed from the assemblages documented from treeless desert and steppe regions of Eurasia.

\section{Introduction}

This paper continues a series of surveys throughout arid regions of Eurasia, reaching from the Caspian Lowland (Novozhilov et al. 2006) and western Kazakhstan (Schnittler \& Novozhilov 2000) over inner mountain basins of the Russian Altay (Novozhilov et al. 2009; Novozhilov et al. 2010) to Mongolia (No- vozhilov \& Golubeva 1986; Novozhilov \& Schnittler 2008) and the Tarim Basin with the adjacent mountains of the eastern Tian-Shan in China (Schnittler et al. 2013) to explore the diversity of myxomycetes in the winter-cold steppes and deserts of Eurasia. Here we present the results of a survey targeting one of the largest geographical regions of the Republic of Kazakhstan, Western Kazakhstan.

The first information on myxomycetes of Western Kazakhstan is provided in the early monograph of A.A. Yachevskiy (1907), which indicates only one species - Mucilago crustacea Wigg. Later, three species: Badhamia utricularis (Bull.) Berk., Fuligo septica (L.) F.H. Wigg., and Lycogala flavofuscum (Ehrenb.) Rostaf. were registered in the woody communities (Vasyagina et al. 1977). The first systematic survey in this region was carried out in 1995 by M. Schnittler, within an expedition led by I.N. Safronova, focusing on the Mangyshlak Peninsula (Schnittler \& Novozhilov 2000; Schnittler 2001), these authors identified 513 myxomycete collections with 27 species, all obtained in moist chamber cultures.

Subsequently, several field trips (2004-2007) in Kazakhstan were conducted by the authors of this paper, resulting in additional myxomycetes species collected over many years with the support of the grant "Planetary Biodiversity Inventions: Global Biodiversity of Eumycetozoans" (NSF grant No. 0316284, Co-principal Investigator Prof. S.L. Stephenson) and several grants of the Russian Foundation of Basic Research (Novozhilov et al. 2003, 2006; Novozhilov, Schnittler \& Zemlyanskaya 2005a, 2005b, 2005c; Zemlyanskaya, Adamonyte \& Krivomaz 2005; Novozhilov \& Zemlyanskaya 2020).

\section{Materials and methods}

\section{Study area}

Western Kazakhstan is an economic and geographical region of the Republic of Kazakhstan and borders in the north with the Russian Federation, and in the south with the republics of Uzbekistan and Turkmenistan. It occupies $736129 \mathrm{~km}^{2}$ (Nursultan, 2008) and centered on the East European Plain (Fig. 1) 


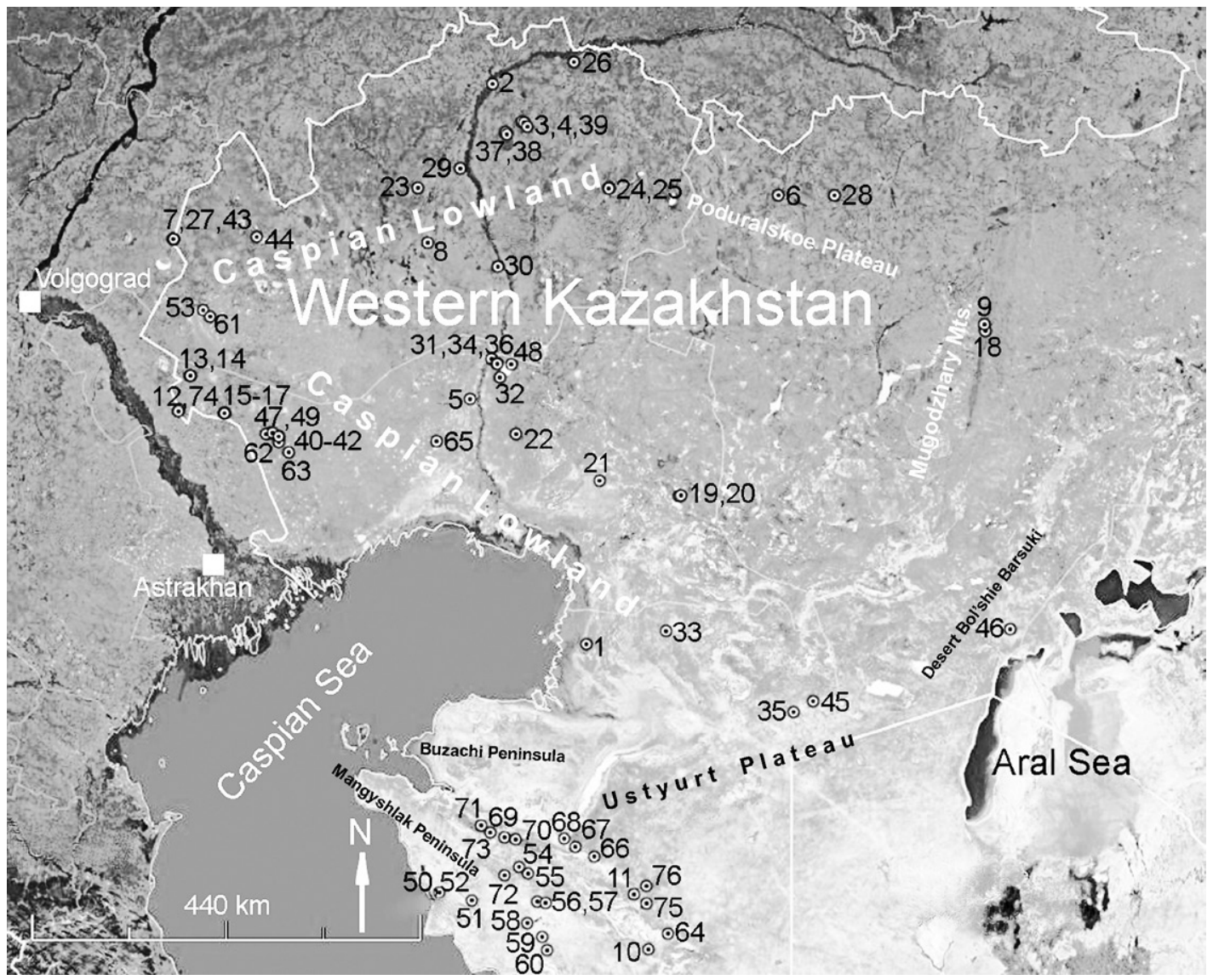

Fig. 1. Schematic map of the study area, numbers and circles indicate the 76 sampled localities.

Map sources: Google Earth (modified).

from the eastern outskirts of the Volga Delta in the west, to the Turan Lowland in the southeast, from the southern spurs of the Urals and Obshchy Syrt in the north, to the Ustyurt Plateau and the coast of the Caspian Sea in the south, including the Mangyshlak Peninsula (Chibilev et al. 2018). In contrast to the uniform sagebrush desert of the Ustyurt Plateau, the desert of the Mangyschlak Peninsula is characterised by a more rugged relief, basically formed by a Plateau furrowed by numerous deep depressions and canyons. Stony badlands dominate, harbouring a scanty vegetation of small shrubs and annual plants. With the exception of some trees around artificial wells, larger trees are absent. The largest rivers of western Kazakhstan, the Ural and Emba, drain into the Caspian Sea basin. Their water is rich in minerals, and this often applies to the ground water in the region, predominant is a mineralization of the sodium chloride-magnesium type (Golub \& Yuritsyna 2013).

The vegetation of Western Kazakhstan can be attributed to the Aral-Caspian (Turan) province of the Iran-Turan region (Ogureeva 2018). There are three main steppe subzones within Western Kazakhstan from north to south: the northern steppe, the middle steppe and the southern steppe, as well as two desert subzones: the northern and 
middle deserts (Chibilev et al.2018). Within Western Kazakhstan, steppes are found in the northern part of the Caspian lowland and on the Poduralskoe Plateau; while deserts occupy the southern part of the Caspian lowland, the Ustyurt plateau and the Mangyshlak Peninsula (Volkova et al. 2003, Safronova et al. 1999a, b; Safronova 2005a, b, 2008, 2010a, b). The region is characterized by an extremely continental, arid climate with long, cold and dry winters $\left(-20--30^{\circ} \mathrm{C}\right)$ alternating with short but hot summers where temperatures can raise up to $42-46^{\circ} \mathrm{C}$, during which $70-90 \%$ of all precipitation falls as rather brief thunderstorms. The study area receives only $160 \mathrm{~mm}$ (in the south) to $320 \mathrm{~mm}$ annual precipitation (in the north). The humidification coefficient increases from $0.1-0.2$ in the south to 0.3 in the north (Golub \& Yuritsyna 2013).

The prevailing type of soil in the studied are is a sandy, weakly alkaline Burozem (light brown soil) with a low content of organic matter. At the same time, salty soils occupy a significant proportion of the region. Thus, salinity, grazing pressure and edaphic moisture are the most important factors determining the vegetation, which often changes over short distances (Chibilev et al. 2018).

The high variation in abiotic conditions, especially mesoclimate and habitat characteristics (mechanical composition and salinity of soils, the degree of moisture, the occurrence of groundwater etc.) sustains a highly diverse vegetation. In the current study, four major habitat types were considered for the ecological analysis of associated myxomycete assemblages. Each locality was assigned to one of these major vegetation types; and the numbers in the following text refer to Fig. 1.

\section{SAGEBRUSH-FEATHERGRASS COMMUNITIES} (DWF) - localities 5-16, 19, 20, 22, 24, 31-35, 37, 40, 42, 44-48, 52, 54, 57, 59, 60, 62, 65-69, 71, 73-76 (Fig. 2a, f, h). This is most common vegetation type in the study area. These communities prevail on loamy, clayey, sandy loam and petrophytic soils with varying degrees of salinity. Plant species composition may vary considerably, but species of sagebrush dominate everywhere, including Artemisia terraealbae Krasch., A. pauciflora Weber ex Stechmann, $A$. lercheana Weber ex Stechmann, and other dwarf shrub species, such as Anabasis salsa Paulsen, A. aphylla L., Alhagi pseudalhagi (M. Bieb.) Desv. ex Shap., Atriplex cana C.A. Mey., Pyankovia brachiata Akhani \& Roalson, Salsola arbusculiformis Drobow, Krascheninnikovia ceratoides (L.) Gueldenst., accompanied by grasses like Stipa capillata L., S. sareptana A.K. Becker, and Festuca rupicola Heuff.

CASPIAN LOWLAND: LOC. 5: 7.8 km northwest of the village Zelenoye, Aksaj river valley, sagebrush white cool desert and grasses communities, $48^{\circ} 10^{\prime} 31^{\prime \prime} \mathrm{N}, 51^{\circ} 27^{\prime} 28^{\prime \prime}$ E. LOC. 7: Dzhanybek research station of the Institute of Forestry of the Russian Academy of Sciences, "Steppe reservation", 49 $23^{\prime} 53^{\prime \prime} \mathrm{N}, 46^{\circ} 47^{\prime} 52^{\prime \prime}$ E. LOC. 8: $6.4 \mathrm{~km}$ south of the village Krasnogorskoye, $49^{\circ} 35^{\prime} 33^{\prime \prime} \mathrm{N}$, $50^{\circ} 39^{\prime} 02^{\prime \prime}$ E. LOC. 12: small depression over clayish ground, temporarily with fresh water, dominated

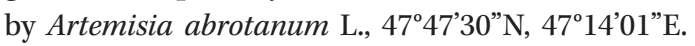
LOC. 13: S-exp. upper slope of the Great Bogdo Mt., $48^{\circ} 08^{\prime} 20^{\prime \prime} \mathrm{N}, 47^{\circ} 20^{\prime} 40^{\prime \prime}$. LOC. 14: stony badlands with half-desert shrubs and many perennial plants, weakly salt-influenced limestone, $48^{\circ} 08^{\prime} 20^{\prime \prime} \mathrm{N}$, $47^{\circ} 20^{\prime} 40^{\prime \prime}$ E. LOC. 15: Azgir Mt., $47^{\circ} 49^{\prime} 43^{\prime \prime} \mathrm{N}$, $47^{\circ} 55^{\prime} 18^{\prime \prime}$ E. LOC. 16: Azgir Mt., $47^{\circ} 49^{\prime} 43^{\prime \prime} \mathrm{N}$, $47^{\circ} 55^{\prime} 13^{\prime \prime}$ E. LOC. 22: $80 \mathrm{~km}$ north of the town Atyrau, Kurajly channel, $47^{\circ} 52^{\prime} 56^{\prime \prime} \mathrm{N}, 52^{\circ} 08^{\prime} 31^{\prime \prime} \mathrm{E}$. LOC. 31: Inder salt-dome hills, Belaya Rostosh, $48^{\circ} 31^{\prime} 34^{\prime \prime} \mathrm{N}, 51^{\circ} 47^{\prime} 52^{\prime \prime}$ E. LOC. 32: south bank of Inder lake, $48^{\circ} 23^{\prime} 36^{\prime \prime} \mathrm{N}, 51^{\circ} 51^{\prime} 32^{\prime \prime}$ E. LOC. 33: 13 $\mathrm{km}$ southwest of the village Opornyj, $46^{\circ} 08^{\prime} 47^{\prime \prime} \mathrm{N}$, $54^{\circ} 19^{\prime} 05^{\prime \prime}$ E. LOC. 34: Inder salt-dome hills, Belaya Rostosh, $48^{\circ} 30^{\prime} 56^{\prime \prime} \mathrm{N}, 51^{\circ} 48^{\prime} 33^{\prime \prime E}$. LOC. 37: Shalkhar lake, peak of a salt dome hill, $50^{\circ} 40^{\prime} 12^{\prime \prime} \mathrm{N}$, 51 ${ }^{\circ} 39^{\prime} 14^{\prime \prime}$. LOC. 40: $6 \mathrm{~km}$ from Bischokho Mt., $47^{\circ} 40^{\prime} 14^{\prime \prime} \mathrm{N}, 48^{\circ} 45^{\prime} 23^{\prime \prime}$ E. LOC. 42: Bischokho Mt., numerous low salt-dome hills elevations with outcrops of the Kungur tier of gypsum, $47^{\circ} 37^{\prime} 10^{\prime \prime} \mathrm{N}$, $48^{\circ} 46^{\prime} 02^{\prime \prime}$ E. LOC. 44: Aschyozek river, $49^{\circ} 30^{\prime} 17^{\prime \prime} \mathrm{N}$, $48^{\circ} 04^{\prime} 37^{\prime \prime}$ E. LOC. 47 : Kudaibergen Mt., $47^{\circ} 41^{\prime} 22^{\prime \prime} \mathrm{N}$, $48^{\circ} 36^{\prime} 42^{\prime \prime}$ E. LOC. 48: Inder salt-dome hills and karst funnels, $48^{\circ} 31^{\prime} 15^{\prime \prime} \mathrm{N}, 52^{\circ} 00^{\prime} 29^{\prime \prime}$ E. LOC. 62: Kudaibergen Mt., $47^{\circ} 40^{\prime} 47^{\prime \prime} \mathrm{N}, 48^{\circ} 34^{\prime} 02^{\prime \prime}$ E. LOC. 65 : $7.8 \mathrm{~km}$ north of the village Jaskayrat, $47^{\circ} 45^{\prime} 52^{\prime \prime} \mathrm{N}$, $51^{\circ} 01^{\prime} 42^{\prime \prime}$ E. LOC. 74: small depression, near Konorterek, $47^{\circ} 48^{\prime} 45^{\prime \prime} \mathrm{N}, 47^{\circ} 14^{\prime} 01^{\prime}$ "E. MUGODZHARY MTS. LOC. 9: Khuchukbaj Mt, $48^{\circ} 58^{\prime} 29^{\prime \prime} \mathrm{N}, 58^{\circ} 36^{\prime} 46^{\prime \prime}$. PODURALSKOE PlateaU: LOC. 6: $3 \mathrm{~km}$ northeast of the village Novoalekseevka, $50^{\circ} 10^{\prime} 03^{\prime \prime} \mathrm{N}$, $55^{\circ} 42^{\prime} 01$ "E. LOC. 19: Embenskoe Plateau, Imankara 

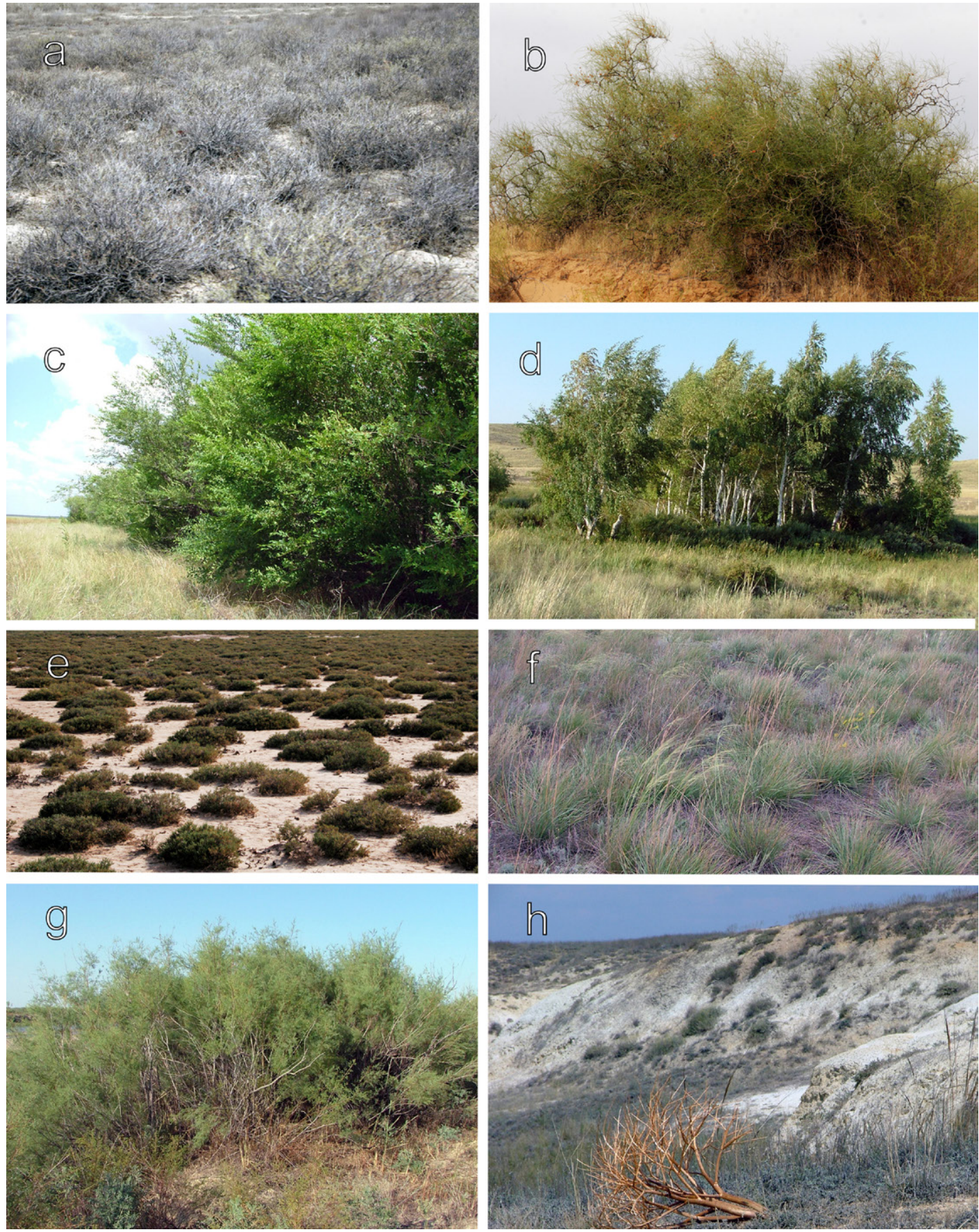

Fig. 2. Images of typical habitats of the study area. a: sagebrush-feathergrass desert community with Artemisia lercheana (DWF), b: sandy desert community with large shrubs Calligonum aphyllum (SHR), c: woody artificial community with Ulmus pumila (F), d: birch wood community "kolk" with Betula pendula (F), f: alluvial sands with Stipa pennata (DWF) e: halophytic community on salt soil with Anabasis salsa (HAL), g: sandy desert with large shrubs Tamarix ramosissima (SHR), h: desert steppe on chalk outcrop with Artemisia pauciflora, Artemisia lercheana, and Anabasis aphylla (DWF). 
Mt., $47^{\circ} 23^{\prime} 38^{\prime \prime} \mathrm{N}, 54^{\circ} 27^{\prime} 50^{\prime \prime}$ E. LOC. 20: $47^{\circ} 23^{\prime} 14^{\prime \prime} \mathrm{N}$, $54^{\circ} 26^{\prime} 21^{\prime \prime}$ E., LOC. 24: $46 \mathrm{~km}$ east of the village Djambejty, Biguly sands, $50^{\circ} 11^{\prime} 20^{\prime \prime} \mathrm{N}, 53^{\circ} 14^{\prime} 29^{\prime \prime} \mathrm{E}$. USTYURT PLATEAU: LOC. 35: $6.3 \mathrm{~km}$ west-southwest of the village Turusch, Sam sands. LOC. 45: $17 \mathrm{~km}$ east of the village Turusch, $45^{\circ} 32^{\prime} 21^{\prime \prime} \mathrm{N}$, $56^{\circ} 16^{\prime} 45^{\prime \prime}$ E. LOC. 66: cliff valley in the Ustyurt Plateau at the NE edge of the Tusbair salt lake, ca. $1 \mathrm{~km}$ SSE of the well Sandui, $53^{\circ} 27^{\prime} 39^{\prime \prime} \mathrm{N} 44^{\circ} 01^{\prime} 22^{\prime \prime}$ E. LOC. 67: stony soil above limestone rocks, near a cliff delimiting the Ustjurt Plateau, near the well Monata, $53^{\circ} 12^{\prime} 32^{\prime \prime} \mathrm{N} 44^{\circ} 06^{\prime} 11^{\prime \prime}$ E. LOC. 68: cliffs delimiting the Ustyurt Plateau, falling down to the Kaidak salt lake, ca. $2 \mathrm{~km} \mathrm{NE}$ of the spring Okbai, $53^{\circ} 3^{\prime} 35^{\prime \prime} \mathrm{N}$ $44^{\circ} 10^{\prime} 25^{\prime \prime}$ E. MANGYSCHLAK PENINSULA: LOC. 10: loose sand dunes above red sandstone hills, Karaschek Mts. in the NW part of the Karünjarük sand dunes, $43^{\circ} 10^{\prime} 37^{\prime \prime} N, 54^{\circ} 11^{\prime} 23$ ”E. LOC. 11 : loose, sandy soil between sandstone boulders, teracces of a cliff slope forming the Kolbai Mts., W margin of the Ustyurt Plateau, $43^{\circ} 41^{\prime} 23^{\prime \prime N}, 53^{\circ} 59^{\prime} 18^{\prime \prime}$ E. LOC. 52: near the eastern margin of the depression Karagije, $43^{\circ} 34^{\prime} 11^{\prime \prime} \mathrm{N}, 51^{\circ} 26^{\prime} 36^{\prime \prime}$ E. LOC. 54: ca. $2 \mathrm{~km} \mathrm{~N}$ of the Baskuduk sand dunes, on the margin of giant chalk cliffs falling up to a depression, $52^{\circ} 28^{\prime} 51^{\prime \prime} \mathrm{N}$, 4352'39”E. LOC. 57: stony soil between limestone plates, margin of the Plateau to the depression Usen, NE edge, $43^{\circ} 33^{\prime} 21^{\prime \prime} \mathrm{N}, 52^{\circ} 50^{\prime} 40^{\prime \prime}$ E. LOC. 59: ca. $5 \mathrm{~km}$ $\mathrm{N}$ Mt. Kunabai, small sandstone hills, $43^{\circ} 13^{\prime} 53^{\prime \prime} \mathrm{N}$ $52^{\circ} 48^{\prime} 49$ "E. LOC. 60: ca. $10 \mathrm{~km}$ SSE Mt. Kunabai, on the Plateau margin, $43^{\circ} 06^{\prime} 27^{\prime \prime} N, 52^{\circ} 53^{\prime} 00^{\prime \prime}$ E. LOC. 69: ca. $12 \mathrm{~km}$ W Schetpe, hills on the $\mathrm{N}$ margin of the eastern Karatau mountains, $44^{\circ} 08^{\prime} 41^{\prime \prime} \mathrm{N}, 52^{\circ} 16^{\prime} 28^{\prime \prime}$. LOC. 71: ca. 16 km NW Schetpe, western Karatau Mts., $44^{\circ} 14^{\prime} 20^{\prime \prime} \mathrm{N}, 51^{\circ} 57^{\prime} 31$ ”E. LOC. 73: ca. $5.5 \mathrm{~km}$ NW Schetpe, foothills at the E margin of the Karatau Mts., $44^{\circ} 10^{\prime} 45^{\prime \prime} \mathrm{N} 52^{\circ} 04^{\prime} 58^{\prime \prime}$ E. LOC. 75: small valley of the creek from the salt spring Ukere, SW edge of the Ustyurt Plateau, $43^{\circ} 36^{\prime} 38^{\prime \prime} \mathrm{N}, 54^{\circ} 09^{\prime} 12^{\prime \prime E}$. LOC. 76: on the W margin of the Karünjarük sand dunes, SW edge, ca. $5 \mathrm{~km} \mathrm{~N}$ of the well Seksorka, $43^{\circ} 46^{\prime} 25^{\prime \prime} \mathrm{N}$, $54^{\circ} 08^{\prime} 50^{\prime \prime} \mathrm{E}$.

WOODY COMMUNities (F) - localities 2, 3, 18, 23, $25-30,39,43,53,61$ (Fig. 2c,d). In the study area there are different types of intrazonal woody communities, mainly with Acer negundo L., Betula pendula Roth, Crataegus ambigua A.K. Becker, C. monogyna Jacq., Malus praecox (Pall.) Borkh., Pyrus communis L., Rhamnus cathartica L., and Ulmus glabra Huds. Artificial woody plantations with Ulmus pumila L., Acer negundo, Pinus sylvestris L., Lonicera tatarica L., and Elaeagnus angustifolia L. are found throughout the region. Woody communities provide in arid regions almost all habitats typically found in temperate forests.

CASPIAN LOWLAND: LOC. 2. $12 \mathrm{~km}$ south of the city Uralsk, Ural floodplain, bank of the lake, inundated poplar woodland with Salix alba L. and Populus nigra L. $51^{\circ} 06^{\prime} 50^{\prime \prime} \mathrm{N}, 51^{\circ} 23^{\prime} 19^{\prime \prime}$ E. LOC. 3. Shalkhar lake, dry steppe, woody plantation with U. pumila, $50^{\circ} 46^{\prime} 31^{\prime \prime} \mathrm{N}, 51^{\circ} 52^{\prime} 57^{\prime \prime}$ E. LOC. 23. Caspian Lowland, $50 \mathrm{~km}$ west village Chapaev, woody plantation with $U$. pumila, $50^{\circ} 05^{\prime} 45^{\prime \prime} \mathrm{N}, 50^{\circ} 25^{\prime} 23^{\prime \prime} \mathrm{E}$. LOC. 27. Dzhanybek research station, woody community with $E$. angustifolia, $49^{\circ} 23^{\prime} 50^{\prime \prime} \mathrm{N}, 46^{\circ} 47^{\prime} 51^{\prime \prime} \mathrm{E}$. LOC. 29. $3 \mathrm{~km}$ WSW of the village Khozheharovo (Zhanabulak), woody community with U. pumila, E. angustipholia, Lonicera tatarica, $50^{\circ} 18^{\prime} 14^{\prime \prime} \mathrm{N}$, $51^{\circ} 01^{\prime} 38^{\prime \prime}$ E. LOC. 30. $6,3 \mathrm{~km}$ northwest of the Antonovo, inundated poplar forest with Populus alba L., Typha laxmannii Lepech., Alhagi pseudalhagi, $49^{\circ} 24^{\prime} 49^{\prime \prime} \mathrm{N}, 51^{\circ} 42^{\prime} 33^{\prime \prime}$ E. Loc. 39: Shalkhar lake, woody community with $U$. pumila and Acer negundo, $50^{\circ} 45^{\prime} 58^{\prime \prime} \mathrm{N}, 51^{\circ} 55^{\prime} 12^{\prime \prime}$. LOC. 43: Dzhanybek research station, different woody communities, $49^{\circ} 23^{\prime} 51^{\prime \prime} \mathrm{N}, 46^{\circ} 47^{\prime} 54^{\prime \prime}$ E. LOC. 53: 2.2 km northwest of the village Urda, woody communities Pinus sylvestris, $48^{\circ} 45^{\prime} 51^{\prime \prime} \mathrm{N}, 47^{\circ} 24^{\prime} 30^{\prime \prime}$ E. LOC. 61. $9.6 \mathrm{~km}$ southeast of the village Urda, small grove with Populus alba in depression, $48^{\circ} 42^{\prime} 45^{\prime \prime} \mathrm{N}, 47^{\circ} 31^{\prime} 41^{\prime \prime} \mathrm{E}$. MUGODZHARY MTS.: LOC. 18. Khuchukbaj Mt., woody community with Populus tremula L., $48^{\circ} 55^{\prime} 00^{\prime \prime} \mathrm{N}$, $58^{\circ} 37^{\prime} 26^{\prime \prime}$ E. poduralskoe plateau: loc. 25. Biguly sands, alluvial sands on macroslope, woody plantations with U. pumila and Elaeagnus commutata Bernh. ex Rydb., 50¹1'59"N, 53¹4'47"E. LOC. 26. east-southeast of the village Danilakol, woody community with $A$. negundo, $51^{\circ} 21^{\prime} 27^{\prime \prime} \mathrm{N}, 52^{\circ} 34^{\prime} 92^{\prime \prime} \mathrm{E}$. LOC. 28. Karavantau upland, woody community with U. pumila and Acer negundo, $50^{\circ} 10^{\prime} 12^{\prime \prime} \mathrm{N}$, $56^{\circ} 30^{\prime} 20^{\prime \prime} \mathrm{E}$.

HALOPHYTIC VEGETATION ON SALTY SOILS (HAL) - localities 1, 4, 17, 21, 38, 41, 49 (Fig. 2e). The study area is characterized by a significant proportion of saline soils, especially around salt lakes. 
Different communities of halophytic plants are common here, variously dominated by e.g. Anabasis salsa, A. aphylla, Halocnemum strobilaceum (Pall.) M. Bieb., Limonium suffruticosum (L.) Kuntze, Atriplex cana, Suaeda salsa (L.) Pall., Salsola paulsenii Litv., Salicornia perennans Willd., Tamarix laxa Willd., and Nitraria schoberi L.

CASPIAN LOWLAND: LOC. 1: the shore of a bay, $9 \mathrm{~km}$ north of village Prorva and $9 \mathrm{~km}$ west of village Sarykamys, $45^{\circ} 59^{\prime} 26^{\prime \prime} \mathrm{N}, 53^{\circ} 15^{\prime} 25^{\prime \prime}$ E. LOC. 17: $900 \mathrm{~m}$ southeast of the village Azgir, Azgir Mt., $47^{\circ} 49^{\prime} 43^{\prime \prime} \mathrm{N}, 47^{\circ} 55^{\prime} 08^{\prime \prime}$ E. LOC. 21: $100 \mathrm{~km}$ south of the village Makat, Berovy hillocks, community with Halocnemum strobilaceum, Artemisia santonicum L., Anabasis salsa, 47 $29^{\prime} 50^{\prime \prime} \mathrm{N}, 53^{\circ} 20^{\prime} 17^{\prime \prime} \mathrm{E}$. LOC. 38: Shalkhar lake, on terrace of lake Shalkar, $50^{\circ} 38^{\prime} 54^{\prime \prime} \mathrm{N}, 51^{\circ} 40^{\prime} 34^{\prime \prime}$ E. LOC. 41: $6 \mathrm{~km}$ southwest from the mountain Bischokho, $47^{\circ} 40^{\prime} 14^{\prime \prime} \mathrm{N}$, $48^{\circ} 45^{\prime} 23^{\prime \prime}$ E. LOC. 49: Kudaibergen Mt., $47^{\circ} 41^{\prime} 51^{\prime \prime} \mathrm{N}$, 48 $39^{\circ}$ '39"E. POdUralskoe plateau: loc. 4: $68 \mathrm{~km}$ north-northwest of the village Djambejty, $50^{\circ} 43^{\prime} 51^{\prime \prime} \mathrm{N}, 51^{\circ} 58^{\prime} 16^{\prime \prime} \mathrm{E}$.

TALL SHRUB COMMUNITIES (SHR) - localities 36, 50, 51, 55, 56, 58, 63, 64 70, 72 (Fig. 2b, g). Sandy deserts are widespread in western Kazakhstan, especially in the Caspian Lowland, where they form large sand dunes in varying degrees of fixation. Sandy soils are mainly covered with Artemisia arenaria DC. and solidified soils are characterized by patches of A. pauciflora. Tall shrub communities with Calligonum aphyllum (Pall.) Gürke, Tamarix ramosissima Ledeb., Ammodendron bifolium (Pall.) Yakovlev, Atraphaxis spinosa L., Convolvulus fruticosus Pall. occur often in sandy landscapes. The only tree-forming species in the desert are Elaeagnus angustifolia and T. ramosissima, being fairly common in sandy depressions.

CASPIAN LOWLAND: LOC. 36: $2 \mathrm{~km}$ west of the town Inderborskii, Ural river terrace, tugay community with Tamarix shrubs on sands, $48^{\circ} 33^{\prime} 36^{\prime \prime} \mathrm{N}, 51^{\circ} 43^{\prime} 09^{\prime \prime}$ E. Loc. 63. $43 \mathrm{~km}$ south of the village Uschtagan, Sam sands, $47^{\circ} 32^{\prime} 03^{\prime \prime} \mathrm{N}$, $48^{\circ} 55^{\prime} 35^{\prime \prime}$ E. MANGYSCHLAK PENINSUla: LOC. 50: sand dunes ca. $25 \mathrm{~km} \mathrm{SE}$ Aktau, on the northern edge of the solontschak Karanol, near the Caspian Sea, $43^{\circ} 28^{\prime} 49^{\prime \prime} N, 51^{\circ} 18^{\prime} 25^{\prime \prime E}$. LOC. 51 : ca. $1 \mathrm{~km}$ NW of the well Sauttuy, E margin of the depression
Karagije, $43^{\circ} 31^{\prime} 23$ "N, $51^{\circ} 52^{\prime} 37^{\prime \prime E}$. LOC. 55: at the NE margin of the Baskuduk sand dunes, $43^{\circ} 49^{\prime} 19^{\prime \prime} \mathrm{N}$, $52^{\circ} 36^{\prime} 08^{\prime \prime}$ E. LOC. 56: sandy soil in a small valley between cliff edges, NW margin of the depression Usen, $43^{\circ} 33^{\prime} 46^{\prime \prime} \mathrm{N}, 52^{\circ} 44^{\prime} 09^{\prime \prime}$ E. LOC. 58: margin of the Tjuesu sand dunes, SEedge, near the margin of a solontschak, ca. $2 \mathrm{~km} \mathrm{~N}$ of the well Besoktui, $43^{\circ} 21^{\prime} 07^{\prime \prime} \mathrm{N}$ 52 36 '53"E. LOC. 64: on the bottom of a depression at the northernmost margin of the Karünjarük sand dunes under the cliffs to the Plateau, $43^{\circ} 20^{\prime} 06^{\prime \prime} \mathrm{N}$ $54^{\circ} 26^{\prime} 14^{\prime \prime}$ E. LOC. 70: stony ground on the bottom of a deep-cut rivulet canyon ca. $4 \mathrm{~km}$ SW Scharmuisch, $\mathrm{N}$ margin of the eastern Karatau Mts., $44^{\circ} 07^{\prime} 59^{\prime \prime} \mathrm{N}$, $52^{\circ} 25^{\prime} 19$ ”'E. LOC. 72: near the Karasasschokui Mt., $43^{\circ} 47^{\prime} 12^{\prime \prime} \mathrm{N}, 52^{\circ} 17^{\prime} 42^{\prime}$ E. SANDY DESERT BOLSHIE BARSUKI: LOC. 46: $4.7 \mathrm{~km}$ southeast of the village Bozoj, $46^{\circ} 11^{\prime} 22^{\prime \prime} \mathrm{N}, 58^{\circ} 52^{\prime} 22^{\prime \prime} \mathrm{E}$.

\section{Substrate sampling}

During our quantitative surveys, a total of 1653 substrate samples from 76 localities (Fig. 1) were collected for moist chamber cultures. These included bark from living trees and shrubs (b) (790 samples), plant leaf litter and litter of grasses and herbaceous plants (l) (539), woody debris (w) (153) and, the dung (d) (171) of herbivorous animals, such as camel, cow, horse, sheep and various rodents. Moist chamber cultures were prepared in the manner described by Härkönen (1977). All cultures consisted of moist filter paper in Petri dishes ( $9 \mathrm{~cm}$ diam.) and were incubated under ambient light and at room temperature $\left(20-24{ }^{\circ} \mathrm{C}\right)$ for up to 90 days and examined for the presence of myxomycetes on six occasions (days 2-4, $6-8,11-14,20-22,40-44$ and $85-90)$. A record is defined herein as one or more fruiting bodies of a species that developed from a moist chamber culture.

To estimate completeness of the survey, the quantitative collection data (every fructification recorded) was used to construct an individual-based species accumulation curve with the program EstimateS (Gotelli \& Colwell 2011, Colwell 2014). Two diversity indices were calculated: Shannon's diversity index $\mathrm{H}^{\prime}=-\sum \mathrm{P}_{\mathrm{i}} \ln \mathrm{P}_{\mathrm{i}}$, where $\mathrm{P}_{\mathrm{i}}$ is the relative abundance (the proportion of the total number of 
individuals or records represented by the $i$ th species) of a particular species (Magurran 2004), and the inverse Simpson's dominance index $\mathrm{D}=1 / \sum \mathrm{P}_{\mathrm{i}}^{2}$. The mean number of species per genus $(\mathrm{S} / \mathrm{G})$ was used as an indicator of overall taxonomic diversity.

Myxomycete assemblages from different habitats and regions were compared by using the adjusted incidence-based Chao-Sørensen index (Chao et al. 2005, 2006). It was computed with EstimateS and used for a cluster analysis by the Wards' method with the program Statistica 10. Graphs were created with SigmaPlot 10.0. Species classified as singletons were excluded from the abovementioned analysis.

All microscopic measurements and observations were made under a light microscope Zeiss Axio Imager A1 with differential interference contrast (DIC). Mean spore diameter was calculated from 10 spore measurements from each collection. Air-dried sporocarps were studied with a Zeiss motorized stereo microscope Discovery V20, and a JSM-6390 LA scanning electron microscope at 10$15 \mathrm{kV}$ at the Core Facility Center of the Komarov Botanical Institute of the Russian Academy of Sciences, St. Petersburg. For the latter, specimens were mounted on copper stubs using double-sided sticky film and sputter-coated with gold. Voucher specimens are deposited in the collection of the first author in the mycological herbarium of the Komarov Botanical Institute RAS, Laboratory of Systematics and Geography of Fungi (LE), the private collection of the third author (sc) and of Grazhina Adamonyte (GA, Vilnus, Lithuania).

\section{Results and Discussion}

The following annotated checklist was compiled based on our quantitative survey. In the annotated species list, each taxon name is followed by an abundance estimation in brackets, including the abundance class according to the ACOR scale (Stephenson 1993), and an indication of the number of records from field / moist chamber cultures. Next, the occurrence of a species in the four different habitat types and in the major substrate types are listed. The abbreviations are explained in the Mate- rials and Methods. The next string preceded by the abbreviation "Loc." lists all localities where a species was found (Fig. 1). Finally, all or some (indicated by the string “...”) specimen numbers are given referring to the herbarium LE. An exclamation mark in superscript (') indicates a species recorded as a new one for Kazakhstan. For the taxa already reported for arid regions of the Lower Volga River Basin (Russia) and Kazakhstan the references are given as numbers in superscript preceding the taxon name: 1 - Vasyagina, Byzova \& Golovenko 1977; 2 - Schnittler \& Novozhilov 2000; 3 - Novozhilov et al. 2003, 4 - Novozhilov, Zemlianskaia \& Schnittler 2005, 5 - Zemlyanskaya, Adamonytė\& Krivomaz 2005, 6 - Novozhilov et al. 2006, 7 - Zemlyanskaya \& Novozhilov 2020.

:Amaurochaete atra (Alb. \& Schwein.) Rostaf. [R, 2/0] F: 2; w: 2; Loc. 43; LE 272607, 272622.

Records of this species are widely scattered throughout the northern hemisphere, being more abundant in coniferous forests on pine coarse wood debris (Eliasson 1977, Adamonytè 2010). However, our findings show that the species appears to be more ecologically plastic and more widely distributed than expected. Both specimens were found on coarse wood debris of Quercus robur L. in the artificial woody plantations and show the typical large aethalioid sporocarps with evanescent peridium and pseudocapillitium represented by branching fan-like plates, which divide into fine threads near the periphery. Spore mass dark brown. Spores redbrown in transmitted light, unevenly warted large warts, $12-15 \mu \mathrm{m}$ diam.

3,4,5Arcyria cinerea (Bull.) Pers. [0, 17/14] F: 31; b: 14, l: 1, w: 16; Loc. 8, 25, 30, 43; LE 273444...

${ }^{5}$ Arcyria denudata (L.) Wettst. [R, 12/0] F: 12; w: 12; Loc. 2, 30, 43; LE 271078...

${ }^{5}$ Arcyria incarnata (Pers. ex J. F. Gmel.) Pers. [R, 6/0] F: 6; b: 1, w: 5; Loc. 18, 27, 43; LE 271047...

${ }^{5}$ Arcyria insignis Kalchbr. \& Cooke [R, 3/0] F: 3; b: 1, w: 2; Loc. 25, 27, 43; LE 271030, 272619, 272624.

${ }^{2,3,4,5,7}$ Arcyria minuta Buchet [R, 2/5] DWF: 2, SHR: 2, HAL: 1, F: 2; b: 3, w: 4; Loc. 7, 36, 38, 42, 43, 50; LE 274179...

${ }^{5}$ Arcyria obvelata (Oeder) Onsberg [R, 4/0] F: 4; w: 4; Loc. 43; LE 271193...

Arcyria occidentalis (T. Macbr.) G. Lister [R, 1/0] F: 1; w: 1; Loc. 43; LE 272618.

The single specimen includes ochre-brown spo- 
rocarps sometimes with a metallic shade, peridium persisting as lobes and fugacious above of sporotheca. Capillitium threads with many free ends are rather thick (3-5 $\mu \mathrm{m}$ wide), ornamented with warts and cogs that often simulate spirals.

${ }^{5,7}$ Arcyria pomiformis (Leers) Rostaf. [R, 4/6] SHR: 1, F: 9; b: 6, w: 4; Loc. 25, 36, 43; LE 271039...

${ }^{5}$ Badhamia affinis Rostaf. [R, 3/0] F: 3; b: 1, w: 2; Loc. 25, 43; LE 271181, 271164, 271165.

${ }^{5}$ Badhamia capsulifera (Bull.) Berk. [R, 3/12] F: 15; b: 15; 25, 39; LE $271180 \ldots$

${ }^{5,7}$ Badhamia foliicola Lister [C, 12/60] DWF: 50, SHR: 4, HAL: 5, F: 13; b: 19, l: 40, w: 13; Loc. 3, 4, 19, 20, 22, 25, 27, 31, 32, 34, 36, 37, 42, 43, 44, 48, 65; LE 271959 ...

${ }^{5}$ Badhamia macrocarpa (Ces.) Rostaf. [R, 6/7] DWF: 1, HAL: 1, F: 11; b: 11, l: 1, w: 1; Loc. 16, 25, 27, 28, 38, 39, 43; LE 272661...

Badhamia panicea (Fr.) Rostaf. [R, 2/4] DWF: 3, F: 3; b: 2, l: 1, w: 3; Loc. 28, 37, 43, 44; LE 271648...

Badhamia rhytidosperma H. W. Keller \& Schokn. [R, 0/3] DWF: 3; b: 3; Loc. 37; LE 271734, 271735, 274005. Fig. 3a-f.

All specimens possess small (1-5 mm wide) white plasmodiocarps (Fig. 2a) with dense lime peridium (Fig. 3f) and are unmistakable by their unique spore ornamentation (Keller \& Schoknecht 1989a). About half the spore surface is wrinkled-reticulate and the remainder is almost smooth (Fig. 3b-e).

${ }_{3,4,5,6,7}$ Badhamia spinispora (Eliasson \& N. Lundq.) H. W. Keller \& Schokn. [A, 0/97] DWF: 64, SHR: 22, HAL: 11; b: 63, l: 13, w: 9, d: 12; Loc. 5, 7, 8, 15, 16 , $17,19,21,31,33,34,35,37,38,40,41,42,44,46,47,48$, 49, 63, 65; LE $279813 .$.

This one of the most abundant species in the study region and characterized by its globose to broadly oval partly smooth spores with spines up to $1 \mu \mathrm{m}$ tall (Keller \& Schoknecht 1989b, Moreno et al. 2011). This species was described as Physarum spinisporum by U. H. Eliasson and N. Lundqvist (Eliasson \& Lundqvist 1979). Its morphology resembles that of Ph. apiculosporum and Badhamia verrucospora but is characterized by globose to broadly oval spores with sharp spines, while Physarum apiculosporum has oval to ellipsoidal spores which are smooth and with two apicula. Badhamia verrucospora has spores similar to those of Ph. apiculosporum, oval to ellipsoid, with two apicula but with small warts which are abundant over half of the spore surface.

${ }^{1,5}$ Badhamia utricularis (Bull.) Berk. [O, 16/12] DWF: 13, SHR: 1, HAL: 2, F: 12; b: 6, l: 16, w: 6; Loc. 3, 4, 5, 24, 25, 31, 36, 38, 42, 43, 48; LE 271068...

${ }^{5}$ Badhamiopsis ainoae (Yamash.) T.E. Brooks \& H.W. Keller [R, 5/0] F: 5; b: 3, w: 2; Loc. 39, 43; LE 271223... (Fig. 3g, h).

This is one of the common corticolous species in the woody plantations of the study region, forming sporocarps on the bark of living trees of Ulmus pumi$l a$ and litter of bark as well. Our collections show the typical minute globose sporocarps with a narrowed base, $0.4-0.8 \mathrm{~mm}$ diam. (Fig. 3g), usually grey or white, with the typical spike-like capillitium processes which remain attached to the peridium (Fig. 3g, h).

Calomyxa metallica (Berk.) Nieuwl. [R, 0/8] F: 8; b: 7, l: 1; Loc. 28, 39; GA 12836-4...

${ }^{5}$ Ceratiomyxa fruticulosa (O.F. Mull.) T. Macbr. [R, 1/0] F: 1; w: 1; Loc. 18; LE 271046.

${ }^{5}$ Comatricha elegans (Racib.) G. Lister [R, 2/3] F: 5; b: 3, w: 2; Loc. 25, 43; LE 271115...

${ }^{5}$ Comatricha ellae Härk. [R, 1/0] F: 1; w: 1; Loc. 25; LE 275778.

${ }^{3,4,5,6}$ Comatricha laxa Rostaf. [O, 5/32] DWF: 4, SHR: 22, HAL: 6, F: 5; b: 30, l: 2, w: 5; Loc. 5, 25, 27, 36, $38,41,43,63$; LE $279819 \ldots$

All specimens belong to the typical corticolous form of this morphological variable species which seems to be common in arid regions (Novozhilov \& Golubeva 198; Schnittler \& Novozhilov 2000, Novozhilov et al. 2003, 2006, 2009, 2010; Novozhilov \& Schnittler 2008). The conspicuous characters of this form are the stiff and coarse capillitial threads, branching from the whole length of the columella.

${ }^{5}$ Comatricha nigra (Pers. ex J.F. Gmel.) J. Schröt. [R, 6/1] HAL: 1, F: 6; b: 1, w: 6; Loc. 38, 43; LE 271838...

${ }^{2,5}$ Comatricha pulchella (C. Bab.) Rostaf. [R, 1/12] DWF: 1, SHR: 6, HAL: 5, F: 1; b: 10, 1: 3; Loc. 10, 25, 36, 38, 49, 50, 58, 70, 71, 75; LE 271027...

${ }^{5}$ Comatricha tenerrima (M.A. Curtis) G. Lister [R, 2/0] F: 2; w: 2; Loc. 43; LE 271195...

${ }^{5}$ Craterium leucocephalum (Pers. ex J.F. Gmel.) Ditmar [R, 8/0] F: 8; 1: 7, w: 1; 43; LE 271117...

${ }^{5}$ Cribraria cancellata (Batsch) Nann.-Bremek. [R, 7/0] F: 7; w: 7; Loc. 2; LE 271076...

${ }^{3,4}$ Cribraria violacea $\operatorname{Rex}[\mathrm{R}, 0 / 15]$ DWF: $1, \mathrm{~F}$ : 14; b: 3, l: 12; Loc. 25, 28, 39, 44; LE 271623...

2,3,4,5,6,7 Didymium anellus Morgan [C, 16/62] 

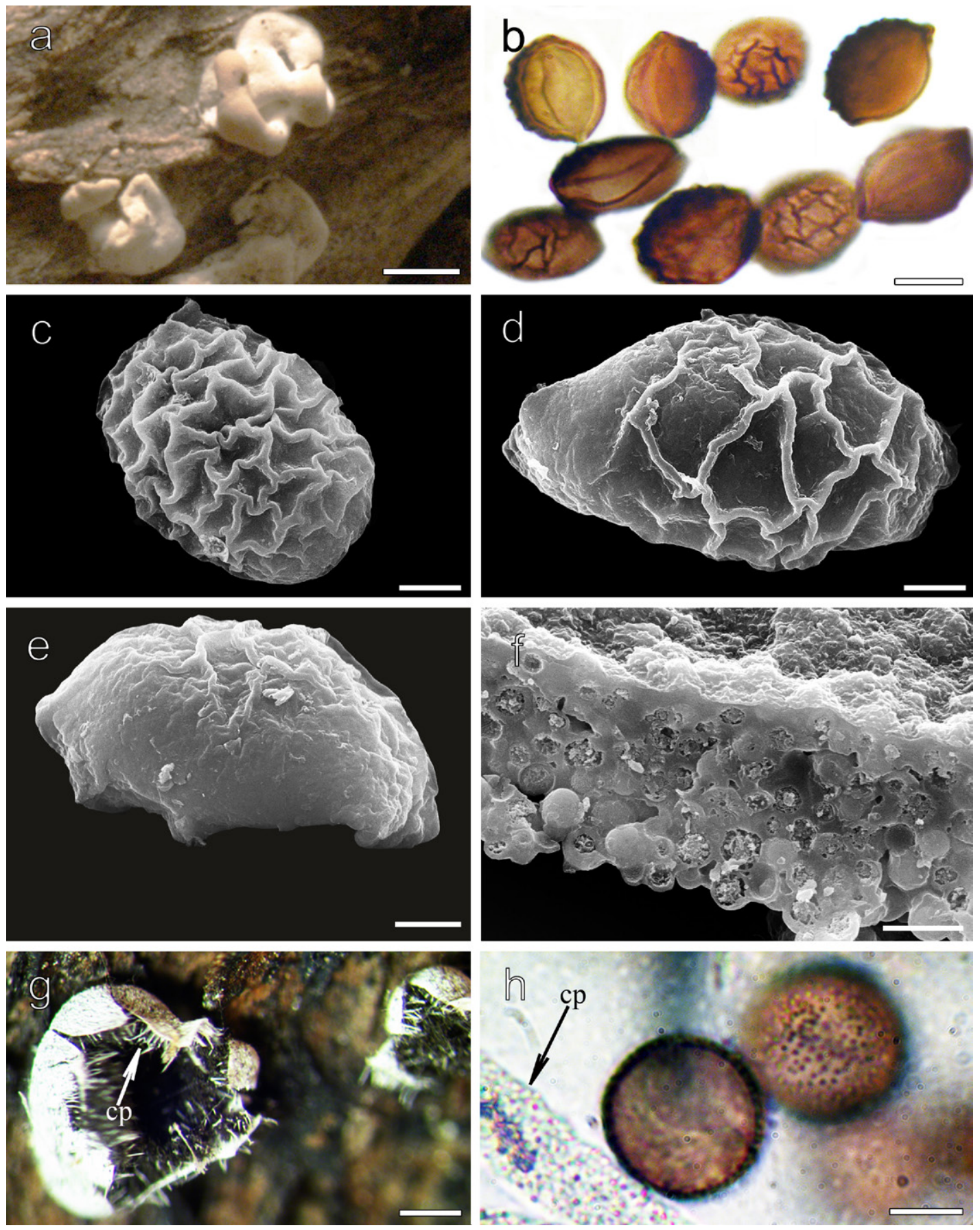

Fig. 3. Morphological traits of sporocarps of encountered rare myxomycete species. a-f: Badhamia rhytidosperma (LE 271734), a: plasmodiocarp, b: spores as seen under dissecting microscope (DM), c-e: spores (SEM), f: peridium (SEM), g-h: Badhamiopsis ainoae (LE 271223), $\mathbf{g}$ - opened sporocarp with spike-like capillitium (cp), $\mathbf{h}$ - spores and capillitium (cp) as seen under dissecting microscope (DM), Scale bars: $a=2 \mathrm{~mm}, b=10 \mu \mathrm{m}$, $d-f=3 \mu \mathrm{m}, \mathrm{g}=100 \mu \mathrm{m}, \mathrm{h}=5 \mu \mathrm{m}$. 
DWF: 33, SHR: 15, HAL: 11, F: 19; b: 24, l: 45, w: 8, d: 1; Loc. 1, 4, 5, 6, 10, 16, 25, 28, 32, 35, 36, 37, 38, 39, 41, $42,43,44,45,48,49,50,51,52,54,56,58,62,67,68,71$, 72, 75; LE $272569 .$.

${ }^{2,5}$ Didymium annulisporum H.W. Keller \& Schokn. [R, 0/1] SHR: 1, d: 1; Loc. 10; sc 6859

${ }^{5}$ Didymium clavus (Alb. \& Schwein.) Rabenh. [O, 19/0] F: 19; b: 3, l: 12, w: 4; Loc. 3, 39, 43; LE 271069 ...

${ }^{5}$ Didymium crustaceum Fr. [R, 6/2] DWF: 1, HAL: 1, F: 6; l: 5, w: 3; Loc. 3, 4, 25, 37, 43; LE 271065...

2,3,4,5,6,7 Didymium difforme (Pers.) Gray [C, 0/64] DWF: 41, SHR: 10, HAL: 6, F: 7; b: 40, l: 14, w: 3, d: 7; Loc. $1,5,8,11,12,14,15,16,19,20,21,25,28,29,32$, $33,36,37,40,41,45,47,48,51,52,54,56,60,64,65,67$, 68, 71; 76 LE 220373...

${ }^{5,7}$ Didymium dubium Rostaf. [O, 4/18] DWF: 6, SHR: 4, HAL: 5, F: 7; b: 4, l: 16, w: 2; Loc. 4, 20, 21, 25, 34, 36, 38, 42, 43; LE 273685...

${ }^{2,3,4,5,6,7}$ Didymium inconspicuum Nann.Bremek. \& D. W. Mitch. [R, 0/12] DWF: 5, SHR: 6, HAL: 1, b: 3, l: 3, w: 1, d: 5; Loc. 10, 16, 36, 41, 47, 50, 51, 56, 58, 59, 67, 76; LE 274885...

The main distinguishing features of this species are rather flat small (0.4-0.7 mm diam.) sessile sporocarps, scattered over the substrate, ochraceous, greyish white or dark brown; with a well developed capillitium and large $(12-14 \mu \mathrm{m})$ spores ornamented evenly with small warts.

${ }^{3,4,5}$ Didymium iridis (Ditmar) Fr. [R, 0/12] DWF: 7, HAL: 5, b: 4, l: 5, w: 2, d: 1; Loc. 8, 16, 37, 38, 44; LE 279849...

${ }^{5}$ Didymium mexicanum G. Moreno, Lizárraga \& Illana [R, 1/1] HAL: 1, F: 1; 1: 2; 38, 43; LE 271842, 253227.

${ }^{5}$ Didymium nigripes (Link) Fr. [R, 12/4] DWF: 1, HAL: 3, F: 12; b: 2, l: 11, w: 3; Loc. 3, 21, 38, 43, 44; LE 271108...

The specimen has typically spores that appear polygonal in optical section, 14-16(-18) $\mu \mathrm{m}$ diam., ornamented with warts united by ridges into a reticulum.

${ }^{2,4,5,6}$ Didymium squamulosum (Alb. \& Schwein.) Fr. [O, 21/25] DWF: 12, SHR: 3, HAL: 6, F: 25; b: 12, l: 21, w: 10, d: 3; Loc. 2, 3, 4, 8, 9, 13, 16, 21, 25, 28, 37, 38, 39, 43, 44, 64, 71; LE 271080 ...

${ }^{4,5,6}$ Didymium trachysporum $\mathrm{G}$. Lister [C, 0/49] DWF: 44, SHR: 2, HAL: 3; b: 31, l: 6, w: 7, d: 5; Loc. 12, $15,19,21,35,37,38,41,42,44,62$, 65; LE 272659...
${ }^{5}$ Diderma spumarioides (Fr.) Fr. [R, 1/0] F: 1; l: 1; Loc. 39; LE 271234.

'Dianema corticatum Lister [R, 0/11] DWF: 1, SHR: 5, F: 5; b: 9, l: 1, w: 1; Loc. 22, 25, 28, 35, 39; LE 273975...

${ }^{2,5}$ Echinostelium arboreum H.W. Keller \& T.E. Brooks [O, 0/17] DWF: 6, SHR: 11; b: 16, w: 1; Loc. 10, $14,51,54,56,58,59,68,71,76$; sc6809...

Echinostelium brooksii K.D. Whitney [R, 0/1] F: 1; b: 1; Loc. 28; GA 12833-6.

Echinostelium coelocephalum T.E. Brooks \& H.W. Keller [R, 0/1] SHR: 1; b: 1; Loc. 63; LE 276378.

${ }^{2,5,7}$ Echinostelium colliculosum K.D. Whitney \& H.W. Keller [A, 0/128] DWF: 65, SHR: 36, HAL: 6, F: 21; b: 109, l: 13, w: 6; Loc. 6, 10, 11, 19, 20, 21, 22, 25, $28,29,31,34,35,39,45,46,48,49,50,51,54,55,56,58$, 59, 60, 62, 63, 71, 72, 73, 75, 76; LE 273469.

Large colonies of shining, pinkish or colorless, very small (60-100 $\mu \mathrm{m}$ tall) sporocarps, spores clustered in groups of 20-50, bearing pads at points of spore-to-spore contact, always with a spore-like columella.

${ }^{7}$ Echinostelium elachiston Alexop. [R, 0/3] DWF: 3; b: 2, w: 1; Loc. 31, 48; LE 272034, 272053, 272000 .

${ }^{2,5,7}$ Echinostelium minutum de Bary [O, 0/17] DWF: 8, SHR: 6, F: 3; b: 10, l: 3, w: 2, d: 2; Loc. 7, 28, 35, $36,44,50,63,71,76$; LE 274175 ...

2,3,4,5,6,7 Fuligo cinerea (Schwein.) Morgan [C, 0/92] DWF: 59, SHR: 29, HAL: 3, F: 1; b: 52, l: 26, w: 2, d: 12; Loc. 5, 8, 15, 16, 31, 33, 34, 35, 36, 37, 38, 39, 40, 41, 42, 44, 46, 47, 48, 62, 63, 65; LE $279870 .$.

This species very common in western Kazakhstan, appearing in moist chamber cultures and are almost invariably associated with litter and dung. Usually our specimens include many small pale grey or white aethalia. The spores are somewhat ellipsoid, (10-)13-14(-15) $\mu \mathrm{m}$ diam., verruculose or spinulose, warts and spines often united by narrow ridges into a broken reticulum.

${ }^{5}$ Fuligo intermedia T. Macbr. [R, 2/0] F: 2; 1: 2; Loc. 2; LE 271096, 271097.

1,5 Fuligo septica (L.) F. H. Wigg. [R, 7/0] F: 7; 1: 1, w: 6; Loc. 23, 30, 43; LE 271245...

${ }^{5}$ Hemitrichia karstenii (Rostaf.) Lister [O, 2/29] F: 31; b: 27, l: 2, w: 2; Loc. 25, 28, 39; LE 271147 ...

Our specimens include sporocarps with a capillitium forming a network of threads loosely and 
irregularly ornamented by spirals, interrupted by numerous vesicules and swollen bodies.

${ }^{7}$ Hemitrichia pardina (Minakata) Ing [R, 0/9] DWF: 3, F: 6; 1: 9; Loc. 7, 9, 25, 34, 39; LE 274188...

${ }^{16}$ Kelleromyxa fimicola (Dearn. \& Bisby) Eliasson [R, 0/3] DWF: 3; d: 3; Loc. 7; LE 274202, 275959, 274210

As stated in several papers, this species exhibits a strong preference for dung (Eliasson 2013, Erastova et al. 2013).

${ }^{5}$ Lamproderma scintillans (Berk. \& Broome) Morgan [R, 1/3] DWF: 2, F: 2; b: 1, l: 2, w: 1; Loc. 9, 39, 43; LE $271194 \ldots$

${ }^{3,4,6,7}$ Licea belmontiana Nann.-Bremek. [R, 0/2] DWF: 1, F: 1; b: 1, l: 1; Loc. 39, 48; LE 271912, 253505.

${ }^{2,5}$ Licea biforis Morgan [R, 0/12] DWF: 1, F: 11; b: 12; Loc. 25, 39, 49, 75; sc 6893, GA 12724-5...

Licea chelonoides Nann.-Bremek. [R, 0/1] DWF: 1, b: 1; Loc. 19; LE 273497.

2,3,4,5,7 Licea denudescens $\mathrm{H}$. W. Keller \& T. E. Brooks [C, 0/69] DWF: 33, SHR: 6, F: 30; b: 43, l: 17, w: 8, d: 1; Loc. 6, 19, 20, 25, 28, 29, 32, 34, 35, 36, 37, 39, 44, 45, 48, 55, 62, 71; LE 220437.

This species was recorded as well from the Caspian Lowland, Mongolia and eastern Kazakhstan (Novozhilov et al. 2006, Novozhilov \& Schnittler 2008, Zemlyanskaya \& Novozhilov 2010, 2018).

${ }^{2,5}$ Licea kleistobolus G.W. Martin [O, 0/35] DWF: 16, SHR: 13, F: 6; b: 28, l: 7; Loc. 10, 19, 25, 39, $44,49,50,51,54,56,68,72,75,76$; LE $273534 .$.

${ }^{7}$ Licea nannengae Pando \& Lado [C, 0/80] DWF: 50, SHR: 13, F: 17; b: 41, l: 34, w: 5; 19, 20, 25, 28, 35, 37, 39, 48, 62, 63; LE 273488...

This species is distinguished from L. belmontiana by its lack of platelets and olivaceous spores without a rose tint (Novozhilov et al. 2006).

Licea operculata (Wingate) G.W. Martin [R, 0/2] DWF: 1, SHR: 1; 1: 2; Loc. 46, 63; LE 274593, 276433.

${ }^{7}$ Licea parasitica (Zukal) G.W. Martin [O, 0/47] DWF: 40, SHR: 5, HAL: 1, F: 1; b: 29, l: 13, w: 5; Loc. 6 , 7, 20, 21, 22, 32, 35, 36, 39, 45, 48, 62; LE 220435...

3,4,6 Licea pusilla Schrad. [R, 0/3] HAL: 3, b: 1, 1: 2; Loc. 38, 41; LE 271885, 272938, 270341.

Licea tenera E. Jahn [R, 0/1] DWF: 1, b: 1; Loc. 37; LE 275955.

${ }^{5}$ Lycogala epidendrum (L.) Fr. [R, 1/0] F: 1; w: 1; Loc. 2; LE 271094.
${ }^{1,5}$ Lycogala flavofuscum (Ehrenb.) Rostaf. [R, 2/0] F: 2; w: 2; Loc. 23, 28; LE 271244, 271051.

:Macbrideola cornea (G. Lister \& Cran) Alexop. [R, 0/3] DWF: 1, F: 2; b: 3; Loc. 39, 44; LE 271904, $271908,271619$.

${ }^{2,3,4,5,7}$ Macbrideola oblonga Pando \& Lado [A, 0/106] DWF: 33, SHR: 40, F: 33; b: 87, l: 7, w: 12; Loc. $7,10,11,14,19,20,25,28,31,35,36,39,45,48,50,51$, $54,58,59,60,62,68,71,76$; LE $274164 . .$.

Our specimens fit well the type description of this species (Pando \& Lado 1988) and are characterized by the absence of a capillitial surface net, the hollow stalk and the oblong shape of the sporotheca. The presence of free spores tell this species apart from M. synsporos. Common in arid regions (Schnittler \& Novozhilov 2000, Novozhilov et al. 2003, Novozhilov et al. 2010).

${ }^{5}$ Metatrichia vesparia (Batsch) Nann.-Bremek. ex G. W. Martin \& Alexop [R, 1/0] F: 1; w: 1; Loc. 18; LE 271045 .

Mucilago crustacea F.H. Wigg. [R, 2/0] F: 2; 1: 2; Loc. 26, 43; LE 273925, 272625.

Oligonema flavidum (Peck) Peck [R, 3/0] F: 3; w: 3; Loc. 30; LE 273458, 273459, 273465.

${ }^{5}$ Oligonema schweinitzii (Berk.) G.W. Martin [R, 5/0] F: 5; w: 5; Loc. 2, 30; LE 271091...

${ }^{2}$ Paradiacheopsis cribrata Nann.-Bremek. [R, 0/4] SHR: 4; b: 4; Loc. 50, 71; sc 6848.

${ }_{3,4,5,7}$ Perichaena chrysosperma (Curr.) Lister [O, 1/30] DWF: 6, SHR: 1, HAL: 1, F: 23; b: 15, l: 15, w: 1; Loc. 7, 9, 25, 28, 36, 38, 39, 44, 48, 62; LE $274190 .$.

2,3,4,5,6,7 Perichaena corticalis (Batsch) Rostaf. [A, 2/113] DWF: 78, SHR: 23, HAL: 9, F: 5; b: 46, l: 47, w: 11, d: 11; Loc. 4, 5, 7, 8, 10, 11, 12, 19, 21, 22, 25, 28, 31, $33,34,35,36,37,38,39,40,42,44,47,48,50,51,58,61$, $63,67,68,71,72,76$; LE 271963...

2,3,4,5,6,7 Perichaena depressa Lib. [A, 0/392] DWF: 279, SHR: 37, HAL: 38, F: 38; b: 154, l: 144, w: 54, d: 40; Loc. 1, 4, 5, 7, 8, 9, 18, 19, 20, 21, 22, 25, 28, 31, $32,33,34,35,36,37,38,39,40,42,44,46,47,48,53,54$, 62, 63, 65, 71, 73; LE 279938...

2,3,4,5,6,7 Perichaena liceoides Rostaf. [A, 0/236] DWF: 180, SHR: 20, HAL: 33, F: 3; b: 69, l: 107, w: 36, d: 24; Loc. 4, 5, 7, 16, 18, 19, 20, 21, 22, 31, 32, 33, 34, $35,36,37,38,39,40,41,42,44,47,48,58,62,65$; LE 271951...

${ }^{7}$ Perichaena luteola (Kowalski) Gilert $[\mathrm{R}, 0 / 9]$ DWF: 9; l: 6, d: 3; Loc. 7, 31, 44, 48; LE 274159... 
This coprophilous myxomycete can be found as well on the litter, as demonstrated by records from eastern Kazakhstan (Zemlyanskaya \& Novozhilov 2018).

Perichaena pedata (Lister \& G. Lister) Lister ex E. Jahn [O, 0/27] DWF: 1, SHR: 1, HAL: 6, F: 19; l: 27; Loc. 4, 9, 25, 28, 35, 39; LE 271950...

Perichaena polygonospora Novozh., Zemly., Schnittler \& S. L. Stephenson [R, 0/2] SHR: 1, F: 1; l: 2; Loc. 39, 63; LE 271941, 276453.

The most distinctive characters of Perichaena polygonospora are the small sporocarps (0.1-0.2 mm diam), the cartilaginous peridium with comparatively large, firmly attached dark peridial protuberances, the absence of a capillitium and especially the polygonal spores. The latter are adorned with large and solid ridges over a surface ornamented with scattered composite large warts $0.3-0.5 \mathrm{~mm}$ tall, which may form clusters that are easily visible by light microscope or may be evenly and densely distributed, in this case being visible only via SEM. This species was found also in arid regions of eastern Kazakhstan (Novozhilov et al. 2008, Zemlyanskaya \& Novozhilov 2018) and Spain (García-Carvajal et al. 2011).

${ }^{6,7}$ Perichaena quadrata T. Macbr. [O, 0/21] DWF: 10, SHR: 9, HAL: 1, F: 1; b: 7, l: 8, w: 5, d: 1; Loc. 34, 35, 36, 37, 38, 39, 48, 74; LE 272078...

${ }_{3,4,5,6,7}$ Perichaena vermicularis (Schwein.) Rostaf. [A, 1/135] DWF: 76, SHR: 41, HAL: 7, F: 12; b: 58, l: 57, w: 19, d: 2; Loc. 1, 4, 7, 10, 19, 21, 22, 25, 31, 32, 34, $35,36,37,39,48,49,50,51,54,55,56,57,58,59,60,62$, 67, 68, 69, 71, 72, 75, 76; LE 220376...

${ }^{5}$ Physarum album (Bull.) Chevall. [R, 10/0] F: 10; b: 1, l: 1, w: 8; Loc. 2, 43; LE 271093...

${ }^{4,7}$ Physarum apiculosporum Härk. [O, 0/23] DWF: 21, HAL: 2; b: 17, l: 2, w: 1, d: 3; Loc. 19, 22, 32 , 34, 37, 38, 42, 44, 62; LE 273481...

Our specimens are all plasmodiocarps; the spores are oval to ellipsoid, smooth, with two pointed ends, one at each end of the spore (Moreno et al. 2011).

Physarum bivalve Pers. [R, 4/0] F: 4; l: 3, w: 1; Loc 43; LE 272589...

2,3.4, 5,6,7 Physarum cinereum (Batsch) Pers. [C, 1/89] DWF: 82, SHR: 3, HAL: 3, F: 2; b: 33, l: 37, w: 19, d: 1; Loc. 5, 16, 19, 20, 21, 22, 25, 31, 32, 34, 36, 37, 38, 39, 41, 42, 44, 45, 47, 48, 71; LE 279999...

${ }^{5,7}$ Physarum compressum Alb. \& Schwein. [O,
0/32] DWF: 31, HAL: 1; b: 26, l: 1, w: 5; Loc. 8, 19, 20, 21, 22, 31, 32, 37, 48; LE 280001...

${ }^{2,5}$ Physarum confertum T. Macbr. [R, 0/6] DWF: 4, SHR: 2; b: 6; Loc. 51, 59, 60, 76; sc 6920...

2,3,4,5,7 Physarum decipiens M. A. Curtis [O, 2/36] DWF: 5, SHR: 3, F: 30; b: 28, l: 9, w: 1; Loc. 19, 25, 28, 32, 35, 39, 43, 48, 71; LE 271038...

3,4,5,6 Physarum diderma Rostaf. [R, 0/1] DWF: 1; b: 1 ; Loc. 60; sc 6895...

2,3,4,5,7 Physarum didermoides (Pers.) Rostaf. [O, 3/36] DWF: 35, F: 4; b: 26, l: 5, w: 7, d: 1; Loc. 5, 8, 16, 19, 22, 32, 33, 37, 39, 42, 43, 47, 48; LE 280005...

${ }^{5}$ Physarum gyrosum Rostaf. [R, 0/5] DWF: 3, SHR: 2; b: 2, l: 1, w: 1, d: 1; Loc. 35, 37, 44, 51, 54; LE 275965...

${ }^{5}$ Physarum leucopus Link [R, 1/1] DWF: 1, F: 1; b: 2; Loc. 37, 39; LE 271784, 271226...

${ }^{3,4,5,6}$ Physarum leucophaeum Fr. [R, 6/0] F: 6; b: 1, l: 2, w: 3; Loc. 25, 39, 43, 61; LE 253560...

See comments to Ph. pseudonotabile.

Physarum megalosporum T. Macbr. [R, 0/1] F: 1; b: 1; Loc. 25; GA 12727-4.

2, 3,4, 5, 6,7 Physarum pseudonotabile Novozh., Schnittler \& Okun [A, 10/475] DWF: 320, SHR: 110, HAL: 28, F: 27; b: 202, l: 207, w: 61, d: 15; Loc. 1, 3, 4, 5, $6,7,10,11,13,14,16,19,20,21,22,25,28,29,31,32$, $34,35,36,37,38,39,40,41,42,43,44,45,46,47,48,49$, $50,51,52,54,55,56,57,58,59,60,62,63,66,67,68,69$, 70, 71, 72, 73, 75, 76; LE $220360 \ldots$

Apparently, this taxon is the most abundant myxomycete in winter-cold arid areas of Eurasia. Initially, many samples of this species were mistakenly determined as Ph. notabile or Ph. leucophaeum (Novozhilov et al. 2013). The specimens from the study area display considerable variation in habit, peridial lime distribution, shape and the proportions of stalk and sporotheca, but all these variation was as well recorded in other arid regions (Novozhilov et al. 2006, Novozhilov \& Schnittler 2008, Novozhilov et al. 2013).

Physarum pusillum (Berk. \& M.A. Curtis) G. Lister [R, 0/1] DWF: 1; w: 1; Loc. 37; LE 271698...

:Physarum straminipes Lister [R, 0/7] F: 7; b: 6, l: 1; Loc. 28, 39; GA 12845-6...

${ }_{3,4,5,6,7}$ Physarum vernum Sommerf. [R, 3/2] DWF: 2, F: 3; b: 3, l: 1, w: 1; Loc. 25, 31, 39, 43, 48; LE $271146 \ldots$

${ }^{2,5}$ Protophysarum phloiogenum M. Blackw. \& Alexop. [R, 0/8] DWF: 2, SHR: 3, HAL: 3; b: 5, l: 3; Loc. 
4, 10, 21, 35, 45, 49, 58, 75; LE 271947...

${ }^{5}$ Stemonitis axifera (Bull.) T. Macbr. [R, 2/0] F: 2; w: 2; Loc. 2, 43; LE 271186, 272593.

${ }^{3,4,5}$ Stemonitis fusca Roth [R, 4/2] DWF: 1, HAL: 1, F: 4; b: 2, w: 4; Loc. 2, 19, 38, 43; LE 271081...

${ }^{5}$ Stemonitis herbatica Peck [R, 1/0] F: 1; w: 1; Loc. 28; LE 271101.

${ }^{5}$ Stemonitis pallida Wingate [R, 5/0] F: 5; 1: 1, w: 4; Loc. 2, 26, 30, 39; LE $271190 .$.

${ }^{5}$ Stemonitis splendens Rostaf. [R, 15/0] F: 15; w: 15; Loc. 2, 30, 43; LE 271079...

${ }^{2,5}$ Stemonitis virginiensis Rex [R, 0/1] SHR: 1 ; b: 1; Loc. 71; LE sc 6870.

${ }^{5}$ Stemonitopsis hyperopta (Meyl.) Nann.Bremek. [R, 2/0] F: 2; w: 2; Loc. 43; LE 271137, 271139.

${ }^{5}$ Symphytocarpus confluens (Cooke \& Ellis) Ing \& Nann.-Bremek. [R, 5/0] F: 5; w: 5; Loc. 2, 30, 43; LE $271086 \ldots$

${ }^{5}$ Trichia contorta (Ditmar) Rostaf. [R, 2/0] F: 2; w: 2; Loc. 28, 39; LE 271050, 271224.

\section{Species diversity}

The species list given above was compiled from 3228 records of myxomycetes, of which only 317 are field records and 2911 (90.2\%) obtained in 1653 moist chamber cultures, giving on average 1.76 species per culture. This is a peculiarity of winter-cold arid regions: field specimens occur rarely, but moist chamber cultures appear to be extremely productive and may show up to ten different species in one Petri dish, often with numerous sporocarps. It is a striking contrast to tropical rain forests, where often many moist chambers are unproductive, and if occurring at all, colonies consist of a few sporocarps only (Schnittler \& Stephenson 2002; Stephenson et al. 2004). In general, moist chamber productivity seems to increase with decreasing precipitation.

In total, 111 morphospecies of 31 genera were identified (Supplementary Database S1). We report 21 taxa for the first time for Western Kazakhstan. Seventy-seven species were classified as rare for the whole study region $(\mathrm{R},<0.5 \%$ of all records); most were represented by only one (16) or two (13) records (Fig. 4). The next largest group are species clas- sified as occasionally occurring $(\mathrm{O},>1.5 \%)$, among them are several lignicolous species. Common (C, $<3 \%$ of all records) were Fuligo cinerea (92), Physarum cinereum (90), Licea nannengae (80), Didymium anellus (78), Badhamia foliicola (72), Licea denudescens (69), Didymium difforme (64), and D. trachysporum (49). The smallest group of species was classified as abundant (A, >3\%), but some of them were recorded hundreds of times: Physarum pseudonotabile (485), Perichaena depressa (392), Perichaena liceoides (236), Perichaena vermicularis (136), Echinostelium colliculosum (128), Perichaena corticalis (115), Macbrideola oblonga (106), and Badhamia spinispora (97).

\section{Myxomycete diversity of the study region}

Judged for the study as a whole, values of Chaol indices (Fig. 5, Table 1) suggest that our effort was probably sufficient to recover nearly all species (111 taxa from 3228 records, $93 \%$ complete according to the final figure of the Chaol estimator).

Despite the high number of 111 species recorded, only 20 species were found to be widely distributed (present in 10 or more of the 76 studied localities, Database S1). If species observed in fc and mc are pooled, both species richness and diversity increased significantly from halophytic vegetation on salty soils (HAL: $35, \mathrm{H}^{\prime}=2.9, \mathrm{D}=11.9$ ) over large shrubby communities (SHR: 42 species, $\mathrm{H}^{\prime}=3.0, \mathrm{D}=$ 12.6) to the treeless steppe habitats with sagebrush (DWF: 61 species, $\mathrm{H}^{\prime}=3.0, \mathrm{D}=12.0$ ); most diverse were the woody intrazonal habitats (F: 87 species, $\mathrm{H}^{\prime}=3.9, \mathrm{D}=40.0$; Table 1).

Seen in total, the main substrate types were rather exhaustively sampled, but the completeness varies greatly depending on the substrate type. According to the Chaol estimator computed separately for species accumulation curves from each of the four sampled groups of substrates (Table 2), the survey was complete to $72 \%$ for coprophilous, $87 \%$ for wood-inhabiting, $89 \%$ for litter-inhabiting species, and $92 \%$ for bark-inhabiting species, respectively. 


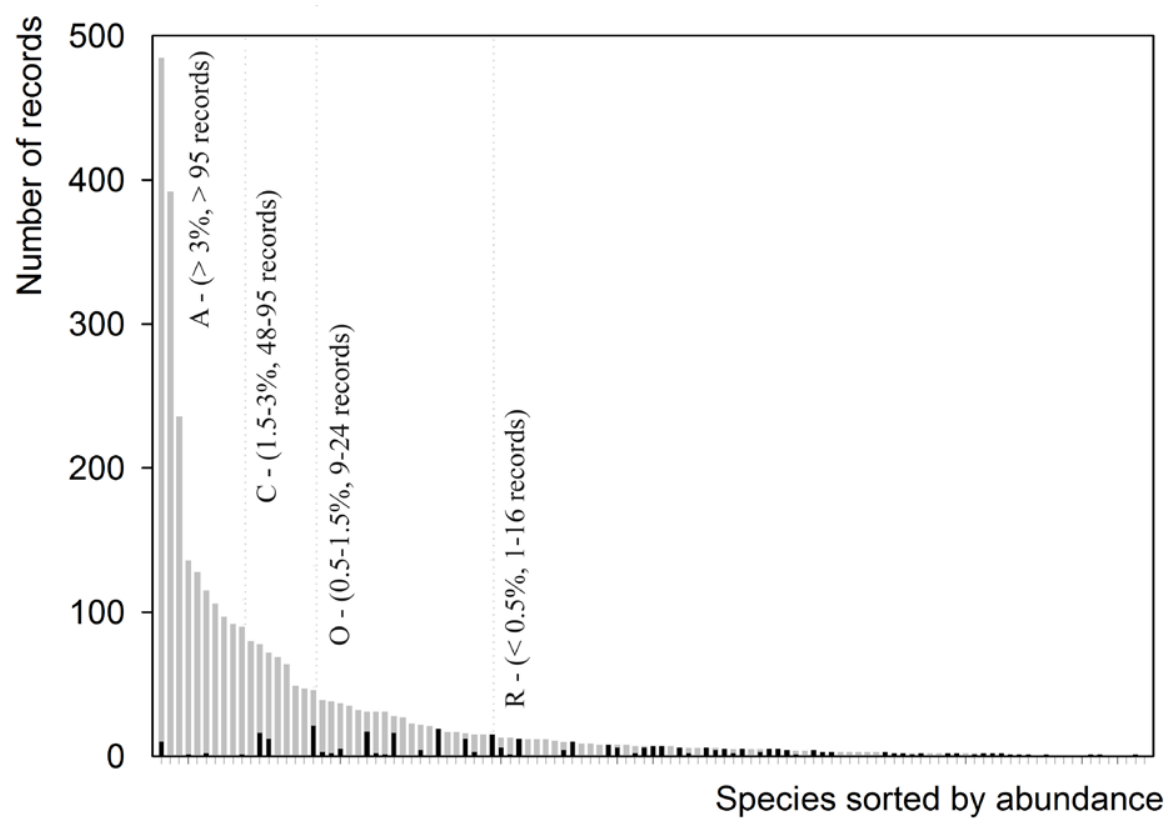

Fig. 4. Frequency distribution of all 3228 determinable records of myxomycetes from 111 species. The black sections of the bars indicate records collected in the field, whereas the grey sections indicate records from 1653 moist chamber cultures. Three thin vertical dotted lines show the delimitation of the ACOR classes.

Similarly, productivity of the moist chamber cultures (expressed as the proportion of positive cultures yielding sporocarps, and the mean number of species per culture) varies among substrate types (Table 2). A pattern of increasing productivity emerges, running from dung $(54 \%, 0.9 \pm 1.2)$, bark $(63 \%, 1.8 \pm 2.2)$, woody debris $(65 \%, 2.0 \pm 2.1)$, to ground litter $(72 \%, 1.8 \pm 1.8)$. As such, for the studied region the moist chamber culture technique seems not only to complement the found species assemblage by species with minute fruit bodies, but also seems to be the most effective method of recovering myxomycetes (Schnittler et al. 2015). This is a difference to warm deserts with a high proportion of succulent plants where many myxomycetes can be found as fruitbodies in the field (Lado et al. 2016).

In addition to obvious features such as absence of trees and succulent plants or the harsh, arid con- ditions, the high (7.5-8.0) $\mathrm{pH}$ of most substrates present seems to be a limiting factor in these steppes and deserts (Schnittler 2001). It is well known that low substrate $\mathrm{pH}$ appears to be a limiting factor for growth and development of most species of myxomycetes (Schnittler et al. 2016). Comparing the results for series of moist chamber cultures prepared from the samples of bark we found that the number of species peaks around a neutral $\mathrm{pH}$ (6.5-7.0). Reasons for the rather basic substrates seem to be the often salty soils, but as well the actual plant substrates formed by numerous and abundant members of the Chenopodiaceae with high $\mathrm{Na}^{+}$and ash contents. These high $\mathrm{pH}$ values may be a reason for absence of most members of the Stemonitidales, Liceales and Trichiales, except for the genus Perichaena which constitutes an exception within the latter order. This very basic $\mathrm{pH}$ is likely a decisive factor accounting 
Table 1. Statistical data for myxomycetes from western Kazakhstan ( $f c$ : from field collections, mc: from moist chamber cultures), grouped according to the four major habitats: treeless sagebrush desert and dry steppe communities (DWF), woody communities (F), large shrubs communities (SHR), halophytic vegetation on salty soils (HAL).

\begin{tabular}{|c|c|c|c|c|c|}
\hline & DWF & $\mathbf{F}$ & SHR & HAL & Whole area \\
\hline Sampled localities & 41 & 14 & 14 & 7 & 76 \\
\hline Records (fc/mc) & $4 / 1764$ & $313 / 401$ & $0 / 526$ & $0 / 220$ & $317 / 2911$ \\
\hline Species (fc/mc, total) & $1 / 61,61$ & $63 / 43,87$ & $0 / 42,42$ & $0 / 35,35$ & $63 / 78,111$ \\
\hline Chao1 \pm SD & $88 \pm 18$ & $97 \pm 7$ & $49 \pm 6$ & $53 \pm 15$ & $120 \pm 6$ \\
\hline Genera & 19 & 27 & 15 & 11 & 31 \\
\hline Species/Genera & 3.2 & 3.2 & 2.8 & 3.2 & 3.6 \\
\hline Shannon $\mathrm{H}^{-}$ & 3.0 & 3.9 & 3.0 & 2.9 & 3.6 \\
\hline Simpson's D & 12.0 & 40.0 & 12.6 & 11.9 & 17.9 \\
\hline Number of $\mathrm{mc}$ & 1087 & 201 & 247 & 159 & 1653 \\
\hline$\%$ mc positive ${ }^{1}$ & 65 & 48 & 81 & 57 & 65 \\
\hline
\end{tabular}

${ }^{1}$ Only cultures that yielded sporocarps were counted as positive.
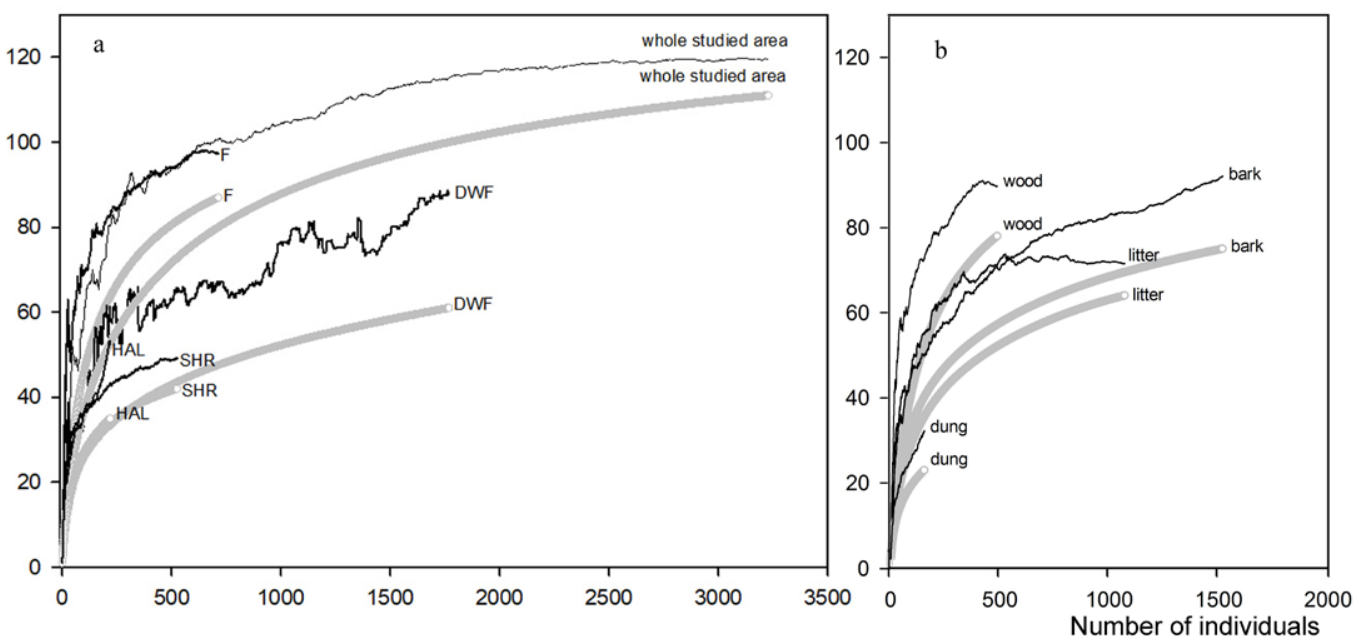

Fig. 5. Individual-based species accumulation curves (thick lines) and the Chao 1 estimator (thin jagged lines) of expected morphospecies richness; a: for the whole studied area and for the four habitat types (DWF - sagebrushfeather communities, SHR - tall shrub communities, HAL - halophytic communities, F - woody communities; b: for the four studied substrate types (bark of living plants, wood, ground leaf and grass litter, dung of animals). 


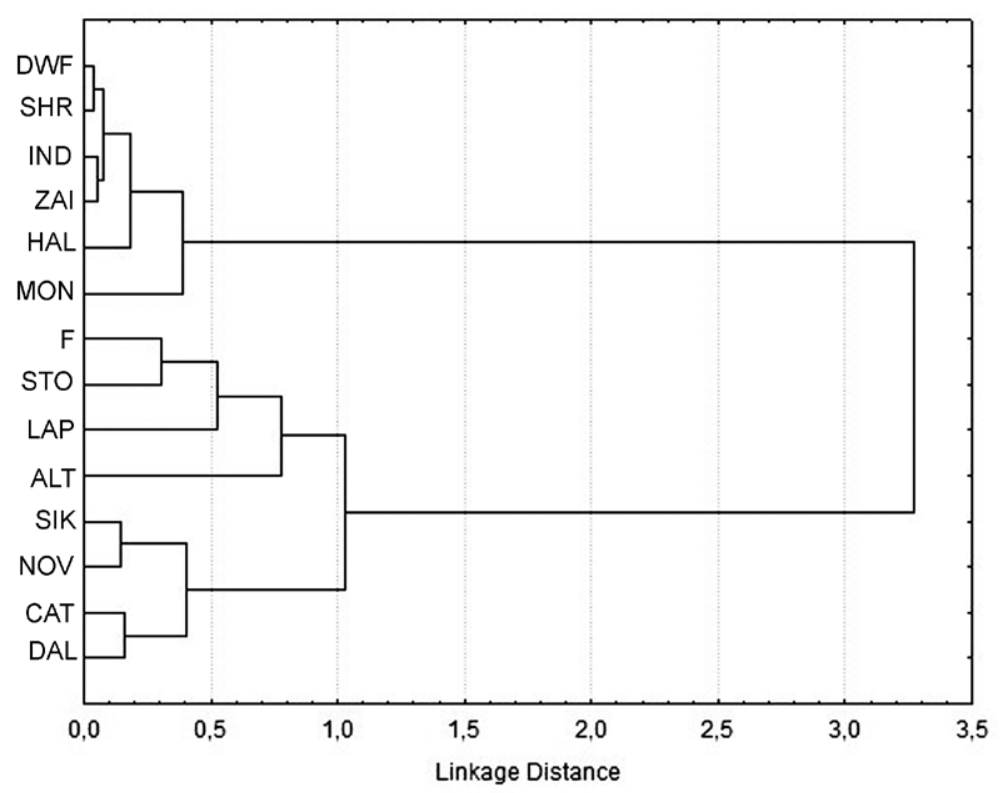

Fig. 6. Dendrogram of similarity based on the abundance-based Chao-Søerensen similarity index (see Table 3, and Database S1 in the supplement) for relative occurrence of 182 myxomycete taxa (singletons were excluded from the analysis). Habitat abbreviations for this study (DWF, SHR, HAL, F) are listed in the text (see Materials and Methods), the regions are abbreviated as IND = arid region, Inder Salt-Dome hills, western Kazakhstan (Zemlianskaya \& Novozhilov, 2020 in press), ZAl = arid region, Zaisan depression, eastern Kazakhstan (Zemlianskaya \& Novozhilov, 2018), $M O N$ =arid region, depression of Great Lakes, western Mongolia (Novozhilov \& Schnittler 2008), STO = dry continental taiga, the State Nature reserve "Stolby", Krasnoyarsk Territory, Russia (Kosheleva et al. 2009), LAP = humid boreal taiga, Laplandskiy Nature Biosphere reserve, Kola Peninsula, Russia (Novozhilov et al. 2020, in press), ALT = dry semiarid woody community, Chuyskaya depression, Altay Mountains, Russia (Novozhilov et al. 2009), SIK = deciduous, mixed broadleaved and moist coniferous forests, Sikhote-Alin Nature Biosphere reserve, Far East, Russia (Novozhilov et al. 2017a), NOV = mixed and moist coniferous forests, Novosibirsk region, Altay Kray, Russia (Vlasenko \& Novozhilov, 2011), CAT = lowland monsoon tropical forests, Cat Tien National Park, Vietnam (Novozhilov et al. 2017b), DAL = mountain tropical forests, Dalat Plateau, Vietnam (Novozhilov et al. 2019).

for the distinctive myxomycete community of in winter cold steppes and deserts. It is noteworthy that there is an exception: Tamarix spp., although known as "salt cedar" provides a rather acidic bark very suitable for some species (Novozhilov et al. 2006; Zemlyanskaya \& Novozhilov 2018).

Summarizing, the myxomycete biota of Western Kazakhstan appear to be rather diverse (111 taxa, $H^{\prime}=3.6, \mathrm{D}=17.9$ ), reflecting the rather high diversity of habitats and vegetation in the study area.
An examination of the proportions of the four families of myxomycetes (as seen according to the traditional nomenclature, compare Leontyev et al. 2019) for each of the four studied habitats shows similarities to other myxomycete biota of arid regions. Treeless arid habitats were relatively rich in Physaraceae (DWF: 24\%, 19 species; HAL: 20\%, 19 species) and Didymiaceae (DWF: 11\%, 9 species; HAL: $22 \%, 10$ species), whereas members of Trichiaceae (DWF: 12\%, 10 species; HAL: 17\%, 
Table 2. Statistical data for myxomycetes from the different substrate types.

\begin{tabular}{|c|c|c|c|c|c|}
\hline & Bark & Litter & Wood & Dung & Total \\
\hline Records (fc/mc) & $46 / 1470$ & $88 / 981$ & $181 / 307$ & $2 / 153$ & $317 / 2911$ \\
\hline Species (fc/mc, total) & $23 / 68,75$ & $19 / 54,64$ & $52 / 38,78$ & $1 / 23,23$ & $63 / 78,111$ \\
\hline Chao1 \pm SD & $92 \pm 12$ & $72 \pm 5$ & $90 \pm 7$ & $32 \pm 9$ & $120 \pm 6$ \\
\hline Genera & 20 & 21 & 24 & 10 & 31 \\
\hline Species/Genera & 3.6 & 3.0 & 3.3 & 2.3 & 3.6 \\
\hline Shannon $\mathrm{H}^{-}$ & 3.5 & 3.1 & 3.7 & 2.5 & 3.6 \\
\hline Simpson's D & 19.7 & 12.5 & 22.0 & 8.1 & 17.9 \\
\hline Number of $\mathrm{mc}$ & 790 & 539 & 153 & 171 & 1653 \\
\hline$\%$ mc positive ${ }^{1}$ & 63 & 72 & 65 & 54 & 65 \\
\hline Species per mc (mean $\pm S D)$ & $1.8 \pm 2.2$ & $1.8 \pm 1.8$ & $2.0 \pm 2.1$ & $0.9 \pm 1.2$ & $0.4 \pm 0.7$ \\
\hline
\end{tabular}

1 Only cultures that yielded sporocarps were counted as positive.

Table 3. Pair wise comparisons of myxomycete assemblages of western Kazakhstan with well studied myxomycete assemblages of Eurasian regions.

$\begin{array}{lllllllllllllll} & \text { DWF } & \text { F } & \text { SHR } & \text { HAL } & \text { IND } & \text { ZAI } & \text { MON } & \text { LAP } & \text { SIK } & \text { CAT } & \text { DAL } & \text { STOL } & \text { ALT } & \text { NOV } \\ \text { DWF } & - & 0.66 & 0.96 & 0.93 & 0.95 & 0.96 & 0.80 & 0.09 & 0.25 & 0.14 & 0.12 & 0.42 & 0.47 & 0.29 \\ \text { F } & 28 & - & 0.57 & 0.48 & 0.51 & 0.55 & 0.46 & 0.43 & 0.48 & 0.45 & 0.30 & 0.70 & 0.43 & 0.68 \\ \text { SHR } & 23 & 20 & - & 0.83 & 0.92 & 0.93 & 0.76 & 0.09 & 0.12 & 0.07 & 0.08 & 0.30 & 0.47 & 0.24 \\ \text { HAL } & 22 & 17 & 17 & - & 0.88 & 0.83 & 0.73 & 0.12 & 0.29 & 0.08 & 0.10 & 0.27 & 0.32 & 0.24 \\ \text { IND } & 22 & 18 & 18 & 15 & - & 0.94 & 0.73 & 0.08 & 0.10 & 0.07 & 0.07 & 0.35 & 0.43 & 0.17 \\ \text { ZAI } & 26 & 20 & 20 & 16 & 19 & - & 0.66 & 0.07 & 0.06 & 0.09 & 0.07 & 0.36 & 0.37 & 0.25 \\ \text { MON } & 14 & 13 & 11 & 10 & 11 & 13 & - & 0.12 & 0.18 & 0.25 & 0.18 & 0.38 & 0.24 & 0.43 \\ \text { LAP } & 10 & 24 & 9 & 8 & 8 & 9 & 8 & - & 0.33 & 0.40 & 0.45 & 0.63 & 0.24 & 0.61 \\ \text { SIK } & 17 & 33 & 13 & 10 & 9 & 12 & 11 & 45 & - & 0.72 & 0.76 & 0.61 & 0.14 & 0.86 \\ \text { CAT } & 15 & 27 & 7 & 7 & 7 & 10 & 9 & 25 & 55 & - & 0.84 & 0.65 & 0.18 & 0.72 \\ \text { DAL } & 103 & 18 & 5 & 6 & 5 & 7 & 7 & 25 & 44 & 44 & - & 0.58 & 0.18 & 0.69 \\ \text { STO } & 19 & 37 & 12 & 10 & 12 & 15 & 9 & 38 & 51 & 36 & 32 & - & 0.35 & 0.85 \\ \text { ALT } & 9 & 13 & 7 & 5 & 8 & 9 & 6 & 8 & 11 & 6 & 7 & 11 & - & 0.40 \\ \text { NOV } & 22 & 41 & 13 & 14 & 13 & 17 & 10 & 44 & 60 & 45 & 39 & 59 & 11 & - \\ \text { Mean } & 0.54 & 0.52 & 0.49 & 0.47 & 0.48 & 0.47 & 0.46 & 0.28 & 0.38 & 0.36 & 0.34 & 0.50 & 0.32 & 0.49 \\ \text { SD } & 0.35 & 0.11 & 0.36 & 0.32 & 0.37 & 0.36 & 0.25 & 0.21 & 0.28 & 0.29 & 0.29 & 0.18 & 0.12 & 0.25\end{array}$

Notes: The total numbers of all specimens observed in the field as well as in moist chamber cultures were used for the calculation of the adjusted abundance-based Chao-Søerensen similarity index. Both the similarity index (upper right) and number of shared species (lower left) are given. Studied habitats in western Kazakhstan and regions are abbreviated as in Fig. 6. 
8 species), and Stemonitidaceae (DWF: 7\%, 6 species; HAL: $9 \%, 4$ species) are much rarer and prefer woody communities. Here, their proportions increase significantly (Trichiaceae: $24 \%, 22$ species; Physaraceae: 24\%, 22 species; Stemonitidaceae 17\%, 15 species; Didymiaceae: $10 \%, 13$ species). It appears that members of Trichiaceae and Stemonitidaceae prefer coarse woody debris and less ecological flexible with respect to substrates.

The taxonomic structure of myxomycete biota in the study region corroborates results from other studies in arid regions of Eurasia (Novozhilov et al. 2006, Novozhilov \& Schnittler 2008, Novozhilov et al. 2009, Novozhilov et al. 2010). The main genera are Physarum (15\%, 17 species), Didymium (11\%, 12 species), Licea (9\%, 10 species), Perichaena (8\%, 9 species), and Badhamia (7\%, 8 species).

A comparision with other myxomycete assemblages from Eurasia (cluster analysis shown in Fig 6) reveals two well-separated clusters: first assemblages from treeless communities (DWF, HAL, SHR, IND, ZAI, MON) from highly arid, continental climates; second those from woody vegetation of different climate zones (STO, LAP, ALT, SIK, NOV, CAT, DAL), but including the intrazonal woody communities of western Kazakhstan (F). This is underpinned by the $\mathrm{C}_{\mathrm{s}}$ similarity values (Table 3 ), where similarities with wooded habitats range below 0.2 but are above 0.8 for a comparison with other arid winter-cold regions of Central Asia (MON: 0.80, IND: 0.95, ZAI: 0.96). Some abundant and common species recovered in this study apparently form the taxonomical nucleus of the myxomycete biota of the cool deserts and steppes of Eurasia (e.g. Physarum apiculosporum, Ph. pseudonotabile, Badhamia spinispora, and Fuligo cinerea). This clearly demonstrates the crucial influence of the microhabitate and substrate conditions (in other words: the microhabitat) on myxomycete occurrence. Within the second cluster, myxomycete assemblages form several subclusters corresponding with major climatic zones: semiarid continental (F, STO), humid boreal (LAP), humid temperate (NOV, SIK) and humid tropical (CAT, DAL). A data analysis of the myxomycete substrate assemblages in western Kazakhstan suggests that this difference is partly due to substrate preferences: in habitat types DWF, HAL, SHR substrate types like tree bark, coarse wood debris or woody litter were in short supply, whereas litter substrates, like leaf and grass litter and dung of animals were overrepresented.

Interestingly, some genera common in the forest biomes, especially in boreal and broad-leaved deciduous forests, like Arcyodes, Barbeyella, Brefeldia, Clastoderma, Collaria, Colloderma, Diachea, Dictydiaethalium, Elaeomyxa, Enerthenema, Leocarpus, Lepidoderma, Lindbladia, Physarella, Prototrichia, Reticularia, Siphoptychium, Stemonaria, Trichioides, and Tubifera, have not been revealed in the arid regions of Kazakhstan even in the intrazonal woody communities (F) with a sufficient supply of coarse wood debris. Further studies using metagenomic analysis of environmental DNA may show if they are present there as amoebal populations that rarely or never fruit or if they are completely absent in the winter-cold deserts and steppes. 


\section{Acknowledgements}

We gratefully acknowledge technical support (SEM) provided by Ludmila A. Kartzeva (The Core Facility Center 'Cell and Molecular Technologies in Plant Science' at the Komarov Botanical Institute RAS, St. Petersburg, Russia). Laboratory work was supported by Russian Foundation for Basic Research (project 18-04-01232 A) and the state program of the Komarov Botanical Institute RAS "Biodiversity, ecology, structural and functional features of fungi and fungus-like protists" (AAAA-A19-119020890079-6); field work was facilitated by a grant (07-04-00353-A; 08-04-10128-k) from the Russian Foundation for Basic Research, and partly by the National Science Foundation (USA) grant DEB 0316284 (head Prof. S.L. Stephenson).

\section{References}

Adamonytè, G. 2010: Lithuanian Stemonitales (Myxomycetes). Genera Amaurochaete and Brefeldia. Botanica Lithuanica 16: 75-82.

Chao, A., Chazdon, R.L., Colwell, R.K. \& Shen, T.J. 2005: A new statistical approach for assessing similarity of species compostion with incidence and abundance data.

Ecology Letters 8: 148-159.

Chao, A., Chazdon, R.L., Colwell, R.K. \& Shen, T.J. 2006: Abundance-based similarity indices and their estimation when there are unseen species in samples. Biometrics 62: 361-371.

Chibilev, A.A., Akhmedenov, K.M. \& Ramazanov,

S.K. 2018: The prospects for the development of the territorial nature protection network in the West Kazakhstan region.

Bulletin of the Orenburg Scientific Center of the Ural Branch of the Russian Academy of Sciences., 4.

DOI: 10.24411/2304-9081-2019-14001. (in Russian).

Colwell, R.K. 2014: EstimateS 9.10 User's Guide. Available from: http://viceroy.eeb.uconn.edu/EstimateS.

Eliasson, U. 2013: Coprophilous myxomycetes: Recent advances and future research directions. Fungal Diversity 59: 85-90.

Eliasson, U.H. \& Lundqvist, N. 1979: Fimicolous myxomycetes. Botaniska notiser 132: 551-568.
Eliasson, U.H. 1977: Ecological notes on Amaurochaete Rost. (Myxomycetes). Botaniska notiser 129: 419-425.

Erastova, D.A., Okun, M.V., Novozhilov, Y.K. \& Schnittler, M. 2013: Phylogenetic position of the enigmatic myxomycete genus Kelleromyxa revealed by SSU rDNA sequences. Mycological Progress 12: 599-608.

García-Carvajal, E., Lado, C. \& Novozhilov, Y.K. 2011:

Myxomycete assemblages from steppes of tabernas and monegros deserts (Spain): biodiversity, ecology and biogeography In: Diamandis, S. \& Topalidou, E. (eds.): XVI Congress of European Mycologists 129-130. Halkidiki.

Golub, V.B. \& Yuritsyna, N.A. 2013: Plant communities of perennial succulents in the Caspian Lowland. Vegetation of Russia 22: 21-28. (in Russian).

Gotelli, N.J. \& Colwell, R.K. 2011: Chapter IV. Estimating species richness. In: Magurran, A.E. \& Mcgill, B.J. (eds.). Biological Diversity Frontiers in Measurement and Assessment, 39-54. Oxford University Press Inc., New York.

Härkönen, M. 1977: Corticolous myxomycetes in three different habitats in southern Finland. Karstenia 17: 19-32.

Keller, H.W. \& Schoknecht, J.D. 1989a: Spore-to-spore cultivation of a new wrinkled-reticulate-spored Badhamia. Mycologia 81: 783-789.

Keller, H.W. \& Schoknecht, J.D. 1989b: Spore-to-spore culture of Physarum spinisporum and its transfer to Badhamia. Mycologia 81: 631-636.

Kosheleva, A.P., Novozhilov, Y.K. \& Schnittler, M. 2009: Myxomycete diversity of the state reserve "Stolby" (south-eastern Siberia, Russia): a preliminary report. Fungal diversity 31: 45-62.

Lado C. An on line nomenclatural information system of Eumycetozoa. Real Jardín Botánico, CSIC. Madrid, Spain. https://eumycetozoa.com/data/index.php, 2005-2020 (consulted 8 June 2020).

Lado, C., Wrigley De Basanta, D., Estrada-Torres, A. \& Stephenson, S.L. 2016: Myxomycete diversity in the coastal desert of Peru with emphasis on the lomas formations. Anales del Jardín Botánico de Madrid 73(1): e032.

Leontyev, D.V., Schnittler, M., StephLadoenson, S., Novozhilov, Y.K. \& Shchepin, O.N. 2019: Towards a p hylogenetic classification of the Myxomycetes. Phytotaxa. 399: 209-238. DOI: 10.11646/phytotaxa.399.3.5. 
Magurran, A.E. 2004: Measuring biological diversity. Blackwell Publishing, Malden, Massachusetts.

Moreno, G., Mitchell, D.W. \& Novozhilov, Y.K. 2011:

A new species of Badhamia (Myxomycetes) confused with other species with similar morphology. Boletín de la Sociedad Micológica de Madrid 35: 137-144.

Novozhilov, Y.K. \& Golubeva, O.G. 1986: Epiphytic myxomycetes from the Mongolian Altai and the Gobi desert. Mikologiya i Fitopatologiya 20: 368. (in Russian).

Novozhilov, Y.K. \& Schnittler, M. 2008: Myxomycete diversity and ecology in arid regions of the Great Lake Basin of western Mongolia. Fungal Diversity 30: 97-119.

Novozhilov, Y.K., Erastova, D.A., Shchepin, O.N., Schnittler, M., Aleksandrova, A.V., Popov, E.S. \& Kuznetsov A.N. 2017b: Myxomycetes associated with monsoon lowland tropical forests in southern Vietnam. Nova Hedwigia 104: 143-182.

Novozhilov, Y.K., Mitchell, D.W. \& Schnittler, M. 2003

Myxomycete biodiversity of the Colorado Plateau. Mycological Progress 2: 243-258.

Novozhilov, Y.K., Okun, M.V., Erastova, D.A., Shchepin, O.N., Zemlyanskaya, I.V., García-Carvajal, E. \& Schnittler, M. 2013: Description, culture and phylogenetic position of a new xerotolerant species of Physarum. Mycologia 105 (6): 1535-1546.

Novozhilov, Y.K., Schnittler M., Erastova, D.A. \& Shchepin O.N. 2017a: Myxomycetes of the Sikhote-Alin State Nature Biosphere Reserve (Far East, Russia). Nova Hedwigia 104: 183-209.

Novozhilov, Y.K., Schnittler, M., Vlasenko, A.V. \& Fefelov, K.A. 2009: Myxomycete diversity of the Chuyskaya depression (Altay, Russia). Mikologiya i Fitopatologiya 43: 522-534.

Novozhilov, Y.K., Schnittler, M., Vlasenko, A.V. \& Fefelov, K.A. 2010: Myxomycete diversity of the Altay Mts. (southwestern Siberia, Russia). Mycotaxon 111: 91-94.

Novozhilov, Y.K., Shchepin, O.N., Gmoshinskiy, V.I. \& Schnittler, M. 2020: Myxomycetes of boreal forests of the Laplandskiy State Nature Biosphere Reserve (Kola Peninsula, Russia). Karstenia (in press).

Novozhilov, Y.K., Shchepin, O.N., Schnittler, M., Dagamac, N.H.A., Alexandrova, A.V., Popov, E.S. \& Kuznetsov, A.N. 2019: Myxomycetes associated with mountain tropical forests of Bidoup Nui Ba and Chu Yang Sin national parks (Dalat Plateau, southern Vietnam). Nova Hedwigia 110: 185-224.
Novozhilov, Y.K., Zemlyanskaya, I.V., Schnittler, M. \& Stephenson, S.L. 2008: Two new species of Perichaena (Myxomycetes) from arid areas of Russia and Kazakhstan. Mycologia 100: 816-822.

Novozhilov, Y.K., Zemlyanskaya, I.V., Schnittler, M. \& Stephenson, S.L. 2006: Myxomycete diversity and ecology in the arid regions of the Lower Volga River Basin (Russia). Fungal diversity 23: 193-241.

Novozhilov, Yu.K., Schnittler, M. \& Zemlianskaia, I.V. 2005a: Synecology of myxomycetes in desert of the northwestern Caspian Lowland. Mikologiya i Fitopatologiya 39: 40-52. (in Russian).

Novozhilov, Yu.K., Zemlianskaia, I.V. \& Schnittler, M. 2005b: Corticolous myxomycctcs in deserts of the northwestern Caspian Lowland. Mikologiya i Fitopatologiya 39: 43 - 54. (in Russian).

Novozhilov, Yu.K., Zemlianskaia, I.V. \& Schnittler, M. 2005c: Myxomycetes of the northwestern Caspian deserts. Novosti Sistematiki Nizshikh Rastenii 38: 164 - 170. (in Russian).

Novozhilov, Yu.K., Zemlianskaia, I.V., Schnittler, M. \& Fefelov, K.F. 2003: An annotated checklist of the myxomycetes of the northwestern Capian Lowland. Mikologiya i Fitopatologiya 37: 53-65.

Nursultan, M.U. 2008: West Kazakhstan: evaluation of the level of the regional development. Bulletin of the Astrakhan State Technological University 2: 245-250. (in Russian).

Ogureeva, G.N. 2018: Ecosystem and biotic diversity of the Caspian region. South of Russia: ecology, development. 13: 8-23. DOI: 10.18470/1992-1098-2018-4-8-23 (in Russian)

Pando, F. \& Lado, L. 1988: Two new species of corticolous Myxomycetes from Spain. Mycotaxon 31: 299-303.

Safronova, I.N. 2005a: About the desert steppes of the Lower Volga. Povolzhskiy Journal of Ecology. 3: 261 - 267. (in Russian).

Safronova, I.N. 2005b: On the phytocenotic diversity of the desert steppes of the Black Sea-Kazakhstan subregion of the Eurasian steppe region. Voprosy Stepevedeniya. 5: 19-27 (in Russian).

Safronova, I.N. 2008: On the problem of the boundary between the steppe and desert zones in the Lower Volga region. Povolzhskiy Journal of Ecology. 4: 334-343 (in Russian). 
Safronova, I.N. 2010a: On the subzonal structure of plant cover in the steppe zone of European Russia. Botanicheskiy Zhurnal 95: 1126-1134 (in Russian).

Safronova, I.N. 2010b: Botanical-geographic division of the Turan deserts as the base of sustainable nature use. Arid ecosystems, 16-2: 47-53 (in Russian).

Safronova, I.N., Ogureeva, G.N., Yurkovskaya, T.K., Miklyaeva, I.M. \& Kotova, T.V. 1999a: Zones and types of zones of vegetation in Russia and adjacent territories. M. 1: 8000000. Map for higher education. Moscow (in Russian).

Safronova, I.N., Ogureeva, G.N., Yurkovskaya, T.K., Miklyaeva, I.M. \& Kotova, T.V. 1999b: Zones and types of zones of v egetation in Russia and adjacent territories. Explanatory notes and legend to the map. Moscow (in Russian).

Schnittler, M. \& Novozhilov, Y.K. 2000: Myxomycetes of the winter-cold desert in western Kazakhstan. Mycotaxon 74: 267-285.

Schnittler, M. 2001: Ecology of Myxomycetes of a winter-cold desert in western Kazakhstan. Mycologia 93: 653-669.

Schnittler, M., Dagamac, N.H.A., Sauke, M., Wilmking, M., Buras, A., Ahlgrimm, S. \& Eusemann, P. 2016: Ecological factors limiting occurrence of corticolous myxomycetes a case study from Alaska. Fungal Ecology 21: 16-23.

Schnittler, M., Novozhilov, Y.K., Shadwick, J.D.L., Spiegel, F.W., García-Carvajal, E. \& König, P. 2015: What substrate cultures can reveal: Myxomycetes and myxomycete-like organisms from the Sultanate of Oman. Mycosphere 6: 356-384.

Schnittler, M., Novozhilov. Y.K., Carvajal. E. \& Spiegel. F.W. 2013. Myxomycete diversity in the Tarim basin and eastern Tian-Shan, Xinjiang Prov., China. Fungal Diversity 59: 91-108.

Stephenson, S.L., Kalyanasundaram, I. \& Lakhanpal, T.N. 1993: A comparative biogeographical study of myxomycetes in the mid-Appalachians of eastern North America and two regions of India. Journal of Biogeography. 20: 645 - 657.

Vasyagina, M.P., Byzova, Z.M. \& Golovenko, I.N. 1977: Flora of spore plants of Kazakhstan, T. X. Lower fungi and Myxomycetes (Phycomycetes et Myxomycetes): 348 p. Nauka. Alma-Ata. KazSSR (in Russian).

Vlasenko, A.V. \& Novozhilov Yu.K. 2011: Myxomycetes of pine forests in the right bank of the Upper Ob' region. Mikologiya i Fitopatologiya 45: 1-13. (in Russian).
Volkova, E.A., Rachkovskaya, E.I., Safronova, I.N., Khramtsov, V.N., Kurochkina, L.Ya., Akzhygitova, N.I., Breckle, S.W., Winkler, G. \& Wucherer, W. 2003: Botanical geography of Kazakhstan and Middle Asia (desert region). Boston-Spectrum, Sankt-Petersburg. (in Russian).

Yachevskiy, A.A. 1907: Mycological flora of European and Asian parts of Russia. Myxomycetes. Izdatelstvo V. Rihtera, Moscow (in Russian).

Zemlyanskaya, I.V. \& Novozhilov, Y.K. 2018: Myxomycete diversity of the Zaisan depression (eastern Kazakhstan). Mikologiya i Fitopatologiya 52: 91-103.

Zemlyanskaya, I.V. \& Novozhilov, Y.K. 2020: Slime Moulds (Myxomycetes $=$ Myxogastrea) in the Inder Salt-Dome Region (western Kazakhstan), Mikologiya i Fitopatologiya.

54: 244-253. (in Russian).

Zemlyanskaya, I.V., Adamonyte், G. \& Krivomaz, T.I. 2005: Preliminary results of myxomycete research expedition to western Kazakhstan. Fungi in natural and anthropogenic ecosystems. Proceedings of the international conference dedicated to the 100-th anniversary of the beginning of Professor A.S. Bondartsev's work at the Komarov Botanical Institute RAS. St. Petersburg. 204-210. (in Russian).

Zemlyanskaya, I.V., Novozhilov, Yu. K. 2010: Myxomycetes from the salt-dome hills near Elton lake. Mikologiya i Fitopatologiya 44: 516-523. (in Russian). 